\title{
ASESMEN OTENTIK: IMPLEMENTASI DAN PERMASALAHANNYA DALAM PEMBELAJARAN BAHASA INGGRIS DI SEKOLAH MENENGAH
}

\author{
M. Zaim \\ Professor in Linguistics at English Department \\ Faculty of Languages and Arts, Universitas Negeri Padang, Indonesia.
}

\begin{abstract}
The aims of this research are to find out the teachers' knowledge about authentic assessment, how to arrange the instruments of authentic assessment, how to implement authentic assessment, the consideration of authentic assessment in deciding final mark of the students, the problems faced by the teachers. The subjects of the research are 10 teachers and 56 students of grade VII and VIII of Junior High School A and B Padang. The data were collected through questionaire, interview, and document analysis. The data were analysed descriptively. The findings of the research are (1) the teachers' knowledge about authentic assessment is good enough to implement authentic assessment based on the standard of authentic assessment; (2) teachers are able to arrange the instruments of authentic assessment, especially on speaking and writing, but because there were various kind of text to be assessed, teachers' knowledge have to be increased; (3) the implementation of authentic assessment is not good enough in the process of learning, (4) teachers still need training and guidance book to implement authentic assessment in learning process.
\end{abstract}

\section{A. PENDAHULUAN}

Kurikulum tingkat satuan pendidikan (KTSP) menyatakan bahwa penilaian yang dilakukan oleh guru harus mengarah pada upaya mengukur ketercapaian kompetensi siswa sesuai dengan tuntutan kurikulum. Kompetensi yang dimaksud pada kurikulum adalah kemampuan yang dapat dilakukan peserta didik yang mencakup pengetahuan, keterampilan dan perilaku. Dengan kata lain, penilaian harus mengacu pada pencapaian standar kompetensi siswa. Salah satu implikasi dari diterapkannya standar kompetensi adalah proses penilaian yang dilakukan oleh guru baik yang bersifat formatif maupun sumatif harus menggunakan acuan kriteria. Untuk itu, dalam menerapkan standar kompetensi guru harus (1) mengembangkan matriks kompetensi belajar (learning competency matrix) yang menjamin pengalaman belajar yang terarah, dan (2) mengembangkan penilaian otentik berkelanjutan (continuous authentic assessment) yang menjamin pencapaian dan penguasaan kompetensi. Penilaian otentik adalah proses pengumpulan informasi oleh guru tentang perkembangan dan pencapaian pembelajaran yang dilakukan anak didik melalui berbagai teknik yang mampu mengungkapkan, membuktikan atau menunjukkan secara tepat bahwa tujuan pembelajaran telah benar-benar dikuasai dan dicapai.

Berdasarkan pengamatan peneliti, di sekolah menengah guru masih cenderung menggunakan model tes dalam asesmennya, baik dalam menilai proses maupun hasil pembelajaran, tanpa menghiraukan apakah itu mengukur aspek kognitif, afektif, maupun psikomotor. Proses penilaian yang biasa dilakukan guru selama ini hanya mampu menggambarkan aspek penguasaan konsep peserta didik. Untuk itu perlu diupayakan suatu teknik penilaian yang mampu mengungkap aspek produk maupun proses, salah satunya dengan menerapkan penilaian otentik.

Pelajaran Bahasa Inggris, sebagai mata pelajaran keterampilan berbahasa seharusnya menekankan pada penilaian otentik, yaitu berupa praktek menyimak (listening), keterampilan berbicara (speaking), membaca (reading) dan menulis (writing). Kecenderungan yang dilakukan di sekolah adalah memfokuskan pada keterampilan memahami bacaan (reading comprehension), sehingga kesempatan untuk berbicara, menulis dan menyimak sangat sedikit. Hal ini akan berakibat pada rendahnya kemampuan berbahasa lisan siswa (listening dan speaking) dan kemampuan menulis (writing). Mereka lebih dibekali dengan kemampuan reseptif (menerima pesan) daripada kemampuan produktif (menyampaikan pesan). Oleh karena itu, kebanyakan lulusan sekolah menengah hanya mampu berbahasa Inggris pasif, bukan berbahasa Inggris aktif.

Hasil pengamatan penulis terhadap pembelajaran bahasa Inggris di Sekolah Menengah Pertama (SMP) menunjukkan bahwa terdapat beberapa masalah yang, menurut para siswa,

ISBN: 978-602-17017-2-0 
menghambat mereka untuk menguasai Bahasa Inggris. Pertama, jarangnya guru berbicara dengan Bahasa Inggris di dalam kelas. Hal ini dirasakan menghambat oleh para siswa karena menurut mereka, mereka jadi tidak terbiasa mendengar orang lain berbahasa Inggris. Kedua, kurangnya kesempatan siswa menggunakan Bahasa Inggris di dalam kelas, akibatnya mereka tidak bisa mempraktekkan kemampuan Bahasa Inggrisnya di sekolah. Ketiga, pembelajaran tatabahasa tidak menjelaskan tentang penggunaannya dalam kehidupan sehari-hari. Banyak siswa yang mahir tatabahasa Inggris tetapi tidak dapat berkomunikasi dengan baik. Keempat, kosa kata yang diajarkan tidak terlalu berguna dalam percakapan sehari-hari. Banyak siswa yang mengeluhkan bahwa katakata yang diberikan oleh guru Bahasa Inggris di sekolah terlalu bersifat teknis, sementara siswa tetap saja mengalami kesulitan untuk mengartikan kata-kata yang banyak digunakan pada film, majalah, surat kabar dan situs-situs internet berbahasa Inggris. Hal ini menunjukkan bahwa pembelajaran bahasa Inggris, termasuk penilaian bahasa Inggris, masih banyak yang belum terkait dengan kebutuhan dunia nyata siswa, yaitu berkomunikasi dengan bahasa Inggris. Proses pembelajaran dan proses penilaian merupakan suatu kesatuan, proses pembelajaran komunikatif hanya bisa dinilai dengan penilaian otentik, yaitu penilaian yang mengukur kemampuan siswa menerima dan menyampaikan informasi dalam bahasa Inggris.

Penerapan penilaian otentik diharapkan bisa memotivasi dan mendorong siswa untuk lebih aktif berbahasa Inggris di kelas dan sekaligus memperbaiki proses pembelajaran bahasa Inggris kearah yang lebih baik. Oleh karena itu, penulis tergelitik untuk melakukan penelitian untuk mengungkapkan "Sejauh mana penilaian otentik telah diimplementasikan dalam pembelajaran bahasa Inggris di SMP?" Sehubungan dengan masalah penelitian di atas, secara lebih rinci penelitian ini menginvestigasi beberapa pertanyaan penelitian sebagai berikut: (1) Bagaimana penyusunan perangkat penilaian otentik oleh guru bahasa Inggris?, (2) Bagaimana pelaksanaan penilaian otentik dalam proses pembelajaran?, (3) Bagaimana pelaksanaan penilaian otentik dalam menilai hasil belajar siswa?, (4) Apa masalah yang dihadapi guru dalam mengimplementasikan asesmen otentik?

\section{Pembelajaran Bahasa Inggris di SMP}

Sebagai salah satu bahasa internasional, bahasa Inggris merupakan alat untuk berkomunikasi secara lisan dan tulis. Berkomunikasi adalah memahami dan mengungkapkan informasi, pikiran, perasaan, dan mengembangkan ilmu pengetahuan, teknologi, dan budaya. Kemampuan berkomunikasi dalam pengertian yang utuh adalah kemampuan berwacana, yakni kemampuan memahami dan/atau menghasilkan teks lisan dan/atau tulis yang direalisasikan dalam empat keterampilan berbahasa, yaitu mendengarkan (listening), berbicara (speaking), membaca (reading) dan menulis (writing). Keempat keterampilan inilah yang digunakan untuk menanggapi atau menciptakan wacana dalam kehidupan bermasyarakat. Oleh karena itu, mata pelajaran Bahasa Inggris diarahkan untuk mengembangkan keterampilan-keterampilan tersebut agar lulusan mampu berkomunikasi dan berwacana dalam bahasa Inggris pada tingkat literasi tertentu (Depdiknas 2006). Tingkat literasi mencakup performative, functional, informational, dan epistemic. Pada tingkat performative, orang mampu membaca, menulis, mendengarkan, dan berbicara dengan simbol-simbol yang digunakan. Pada tingkat functional, orang mampu menggunakan bahasa untuk memenuhi kebutuhan hidup sehari-hari seperti membaca surat kabar, manual atau petunjuk. Pada tingkat informational, orang mampu mengakses pengetahuan dengan kemampuan berbahasa, sedangkan pada tingkat epistemic orang mampu mengungkapkan pengetahuan ke dalam bahasa sasaran (BSNP, 2006).

Pembelajaran bahasa Inggris di SMP/MTs ditargetkan agar peserta didik dapat mencapai tingkat functional yakni berkomunikasi secara lisan dan tulis untuk menyelesaikan masalah seharihari, sedangkan untuk SMA/MA diharapkan dapat mencapai tingkat informational karena mereka disiapkan untuk melanjutkan pendidikan ke perguruan tinggi. Tingkat literasi epistemic dianggap terlalu tinggi untuk dapat dicapai oleh peserta didik SMA/MA karena bahasa Inggris di Indonesia berfungsi sebagai bahasa asing.

Mata Pelajaran Bahasa Inggris di SMP/MTs bertujuan agar peserta didik memiliki kemampuan sebagai berikut: (1) mengembangkan kompetensi berkomunikasi dalam bentuk lisan dan tulis untuk mencapai tingkat literasi functional; (2) memiliki kesadaran tentang hakikat dan pentingnya bahasa Inggris untuk meningkatkan daya saing bangsa dalam masyarakat global; dan (3) mengembangkan pemahaman peserta didik tentang keterkaitan antara bahasa dengan budaya. 40 
Lebih lanjut, Depdiknas (2006) menyatakan bahwa ruang lingkup mata pelajaran Bahasa Inggris di SMP meliputi kemampuan sebagai berikut.

1) Kemampuan berwacana, yakni kemampuan memahami dan/atau menghasilkan teks lisan dan/atau tulis yang direalisasikan dalam empat keterampilan berbahasa, yakni mendengarkan, berbicara, membaca dan menulis secara terpadu untuk mencapai tingkat literasi functional;

2) Kemampuan memahami dan menciptakan berbagai teks fungsional pendek dan monolog serta esei berbentuk procedure, descriptive, recount, narrative, dan report. Gradasi bahan ajar tampak dalam penggunaan kosa kata, tata bahasa, dan langkah-langkah retorika;

3) Kompetensi pendukung, yakni kompetensi linguistik (menggunakan tata bahasa, kosa kata, tata bunyi, dan tata tulis), kompetensi sosiokultural (menggunakan ungkapan dan tindak bahasa secara berterima dalam berbagai konteks komunikasi), kompetensi strategi (mengatasi masalah yang timbul dalam proses komunikasi dengan berbagai cara agar komunikasi tetap berlangsung), dan kompetensi pembentuk wacana (menggunakan piranti pembentuk wacana).

Kemampuan berbahasa Inggris yang hendak dicapai oleh siswa dalam pembelajaran dinyatakan pada kurikulum dalam bentuk Standar Kompetensi (SK) dan Kompetensi Dasar (KD) berbahasa Inggris. Standar kompetensi merupakan kompetensi yang harus dimiliki oleh siswa pada tingkatan pembelajaran tertentu. Kompetensi dasar merupakan rincian kompetensi yang harus dikuasai siswa. Standar kompetensi dan kompetensi dasar menjadi arah dan landasan untuk mengembangkan materi pokok, kegiatan pembelajaran, dan indikator pencapaian kompetensi untuk penilaian. Dalam merancang kegiatan pembelajaran dan penilaian perlu memperhatikan Standar Proses dan Standar Penilaian.

Dalam bahasa Inggris ada empat kompetensi bahasa yang harus dimiliki oleh siswa dalam belajar bahasa Inggris, yaitu mendengarkan (listening), berbicara (speaking), membaca (reading), dan menulis (writing). Standar Kompetensi (SK) dan Kompetensi Dasar (KD) ditetapkan dalam Standar Isi untuk Satuan Pendidikan Dasar dan Menengah oleh Badan Standar Nasional Pendidikan yang ditetapkan dalam bentuk Peraturan Menteri Pendidikan Nasional (Permendiknas) Nomor 22 tahun 2006 (BSNP, 2006).

Standar kompetensi pada kelas VII Semester I untuk empat keterampilan berbahasa tersebut dapat dilihat pada tabel berikut.

Tabel 1: Standar Kompetensi Bahasa Inggris kelas VII Semester I

\begin{tabular}{|l|l|l|l|l|}
\hline No & Listening & Speaking & Reading & Writing \\
\hline 1. & $\begin{array}{l}\text { Memahami makna dalam } \\
\text { percakapan transaksional } \\
\text { dan interpersonal sangat } \\
\text { sederhana untuk } \\
\text { berinteraksi dengan } \\
\text { lingkungan terdekat }\end{array}$ & $\begin{array}{l}\text { Mengungkapkan makna dalam } \\
\text { percakapan transaksional dan } \\
\text { interpersonal sangat } \\
\text { sederhana untuk berinteraksi } \\
\text { dengan lingkungan terdekat }\end{array}$ & $\begin{array}{l}\text { Memahami makna dalam } \\
\text { teks tulis fungsional pendek } \\
\text { sangat sederhana yang } \\
\text { berkaitan dengan lingkungan } \\
\text { terdekat. }\end{array}$ & $\begin{array}{l}\text { Mengungkapkan } \\
\text { dalam teks tulis fungsional } \\
\text { pendek sangat sederhana } \\
\text { untuk berinteraksi dengan } \\
\text { lingkungan terdekat }\end{array}$ \\
\hline 2. & $\begin{array}{l}\text { Memahami makna dalam } \\
\text { teks lisan fungsional } \\
\text { pendek sangat sederhana } \\
\text { untuk berinteraksi dengan } \\
\text { lingkungan terdekat }\end{array}$ & $\begin{array}{l}\text { Mengungkapkan makna dalam } \\
\text { teks lisan fungsional pendek } \\
\text { sangat sederhana untuk } \\
\text { berinteraksi dengan } \\
\text { lingkungan terdekat }\end{array}$ & & \\
\hline
\end{tabular}

Keterampilan mendengarkan dimulai dari kemampuan memahami makna dalam percakapan transaksional dan interpersonal dengan menggunakan ragam bahasa lisan seperti menyapa, memperkenalkan diri, dan memerintah atau melarang. Termasuk dalam keterampilan ini mengucapkan terima kasih, meminta maaf, dan mengungkapkan kesantunan. Sejalan dengan keterampilan mendengarkan, keterampilan berbicara mengungkapkan makna dalam percakapan transaksional dan interpersonal sederhana seperti menyapa, memperkenalkan diri, dan memerintah atau melarang. Termasuk dalam keterampilan ini meminta dan memberi informasi, mengucapkan terima kasih, meminta maaf dan mengungkapkan kesantunan. Keterampilan membaca berhubungan dengan memahami makna dalam teks tulis fungsional pendek sangat sederhana yang berkaitan dengan lingkungan terdekat. Kompetensi dasar diawali dengan membaca nyaring dengan 
memperhatikan ucapan, tekanan dan intonasi. Keterampilan menulis juga sejalan dengan keterampilan membaca yaitu mengungkapkan makna gagasan dalam teks fungsional pendek sangat sederhana untuk berinteraksi dengan lingkungan terdekat.

Secara umum kompetensi berbahasa yang harus dimiliki oleh siswa kelas VII semester I SMP adalah keterampilan berbahasa transaksional dan interpersonal untuk keterampilan mendengarkan dan berbicara, serta teks tulis fungsional pendek sangat sederhana untuk berinteraksi dengan lingkungan terdekat untuk keterampilan berbicara dan menulis.

Tabel 2: Standar Kompetensi Bahasa Inggris kelas VIII Semester I

\begin{tabular}{|c|c|c|c|c|}
\hline No & Listening & Speaking & Reading & Writing \\
\hline 1. & $\begin{array}{lr}\text { Memahami } & \text { makna dalam } \\
\text { percakapan } & \text { transaksional } \\
\text { dan } & \text { interpersonal } \\
\text { sederhana } & \text { untuk } \\
\text { berinteraksi } & \text { dengan } \\
\text { lingkungan sekitar } & \end{array}$ & $\begin{array}{l}\text { Mengungkapkan makna dalam } \\
\text { percakapan transaksional dan } \\
\text { interpersonal lisan pendek } \\
\text { sederhana untuk berinteraksi } \\
\text { dengan lingkungan sekitar }\end{array}$ & $\begin{array}{l}\text { Memahami makna teks tulis } \\
\text { fungsional dan esei pendek } \\
\text { sederhana berbentuk } \\
\text { descriptive dan recount yang } \\
\text { berkaitan dengan lingkungan } \\
\text { sekitar }\end{array}$ & $\begin{array}{l}\text { Mengungkapkan makna } \\
\text { dalam teks tulis fungsional } \\
\text { dan esei pendek sederhana } \\
\text { berbentuk descriptive, dan } \\
\text { recount untuk berinteraksi } \\
\text { dengan lingkungan sekitar }\end{array}$ \\
\hline 2. & $\begin{array}{l}\text { Memahami makna dalam } \\
\text { teks lisan fungsional dan } \\
\text { monolog pendek } \\
\text { sederhana berbentuk } \\
\text { descriptive dan recount } \\
\text { untuk berinteraksi dengan } \\
\text { lingkungan sekitar }\end{array}$ & $\begin{array}{l}\text { Mengungkapkan makna dalam } \\
\text { teks lisan fungsional dan } \\
\text { monolog pendek sederhana } \\
\text { yang berbentuk descriptive } \\
\text { dan recount untuk berinteraksi } \\
\text { dengan lingkungan sekitar }\end{array}$ & & \\
\hline
\end{tabular}

Keterampilan mendengarkan dimulai dari kemampuan memahami makna dalam percakapan transaksional dan interpersonal dengan menggunakan ragam bahasa lisan seperti menolak, memberi, meminta, mengakui, mengingkari fakta, dan meminta dan memberi pendapat. Termasuk dalam keterampilan ini merespon makna yang terdapat dalam monolog pendek sederhana berbentuk descriptive dan recount. Sejalan dengan keterampilan mendengarkan, keterampilan berbicara melatih siswa mengungkapkan makna dalam percakapan transaksional dan interpersonal sederhana seperti meminta, memberi, dan menolak jasa, serta meminta, memberi, dan menolak barang, mengakui, mengingkari fakta, dan meminta dan memberi pendapat. Termasuk dalam keterampilan ini mengungkapkan makna dalam monolog pendek sederhana berbentuk descriptive dan recount. Keterampilan membaca berhubungan dengan memahami makna dalam teks tulis fungsional dan esei pendek sederhana yang berkaitan dengan lingkungan sekitar. Kompetensi dasar diawali dengan membaca nyaring teks fungsional dan esei berbentuk descriptive dan recount. Keterampilan menulis juga sejalan dengan keterampilan membaca yaitu mengungkapkan makna dalam teks tulis fungsional dan esei pendek sederhana berbentuk descriptive dan recount untuk berinteraksi dengan lingkungan sekitar.

Secara umum kompetensi berbahasa yang harus dimiliki oleh siswa kelas VIII semester 1 SMP adalah keterampilan berbahasa transaksional dan interpersonal untuk keterampilan mendengarkan dan berbicara, serta teks tulis fungsional pendek sederhana untuk berinteraksi dengan lingkungan untuk keterampilan berbicara dan menulis.

\section{Penilaian dalam Pembelajaran Bahasa Inggris}

Penilaian (assessment) pendidikan adalah proses pengumpulan dan pengolahan informasi untuk menentukan pencapaian hasil belajar peserta didik (Brown, 2010). Penilaian adalah penerapan berbagai cara dan penggunaan beragam alat penilaian untuk memperoleh informasi tentang sejauh mana hasil belajar peserta didik atau ketercapaian kompetensi (rangkaian kemampuan) peserta didik. Penilaian menjawab pertanyaan tentang sebaik apa hasil atau prestasi belajar seorang peserta didik. Hasil penilaian dapat berupa nilai kualitatif (pernyataan naratif dalam kata-kata) dan nilai kuantitatif (berupa angka). Pengukuran berhubungan dengan proses pencarian atau penentuan nilai kuantitatif tersebut.

Penilaian hasil belajar oleh pendidik dilakukan secara berkesinambungan, bertujuan untuk memantau proses dan kemajuan belajar peserta didik serta untuk meningkatkan efektivitas kegiatan pembelajaran. Penilaian tersebut meliputi kegiatan sebagai berikut (BSNP, 2006): 
1) menginformasikan silabus mata pelajaran yang di dalamnya memuat rancangan dan kriteria penilaian pada awal semester;

2) mengembangkan indikator pencapaian KD dan memilih teknik penilaian yang sesuai pada saat menyusun silabus mata pelajaran;

3) mengembangkan instrumen dan pedoman penilaian sesuai dengan bentuk dan teknik penilaian yang dipilih;

4) melaksanakan tes, pengamatan, penugasan, dan/atau bentuk lain yang diperlukan;

5) mengolah hasil penilaian untuk mengetahui kemajuan hasil belajar dan kesulitan belajar peserta didik;

6) mengembalikan hasil pemeriksaan pekerjaan peserta didik disertai balikan/komentar yang mendidik; dan

7) memanfaatkan hasil penilaian untuk perbaikan pembelajaran.

Rangkaian proses di atas menggambarkan bahwa kegiatan penilaian meliputi semua proses mulai dari persiapan, pelaksanaan, dan setelah pelaksanaan, terutama yang terkait dengan pemanfaatan hasil penilaian.

\section{Penilaian Otentik dalam Pembelajaran Bahasa Inggris}

Beberapa ahli penilaian mengungkapkan pengertian asesmen otentik (authentic assessment). O'Malley dan Pierce (1996:4) mendefinisikan asesmen otentik sebagai berikut, "Authentic assessment is an evaluation process that involves multiple forms of performance measurement reflecting the student's learning achievement, motivation, and attitudes on instructionally-relevant activities." Menurut O'Malley dan Pierce, asesmen otentik merupakan proses evaluasi yang menggunakan berbagai bentuk pengukuran kinerja yang menggambarkan pemerolehan hasil belajar siswa, motivasi dan perilakunya dalam kegiatan pembelajaran. Selanjutnya, Taufina (2009) mendefinisikan penilaian otentik sebagai proses untuk menggambarkan perubahan dalam diri siswa setelah terjadinya proses pembelajaran. Dengan demikian, penilaian tidak lagi sekedar pencapaian tujuan pembelajaran, tetapi merupakan suatu usaha untuk memperoleh berbagai informasi secara berkala, berkesinambungan, dan menyeluruh tentang proses dan hasil belajar siswa.

Haryono (2009) mengemukakan bahwa ada empat prinsip umum penilaian otentik, yaitu: (1) proses penilaian harus merupakan bagian yang tak terpisahkan dari proses pembelajaran, bukan bagian terpisah dari proses pembelajaran (a part of, not apart from instruction); (2) penilaian harus mencerminkan masalah dunia nyata (real world problems), bukan masalah dunia sekolah (school work-kind of problems); (3) penilaian harus menggunakan berbagai ukuran, metoda dan kriteria yang sesuai dengan karakteristik dan esensi pengalaman belajar; dan (4) penilaian harus bersifat holistik yang mencakup semua aspek dari tujuan pembelajaran (kognitif, afektif, dan sensori-motorik). Dengan demikian, asesmen otentik menggunakan prinsip penilaian proses, mencerminkan masalah di dunia nyata, menggunakan kriteria esensi pengalaman belajar, dan bersifat holistik.

Selanjutnya, Imran (2012) menyatakan beberapa karakteristik dari penilaian otentik. Dia menyatakan bahwa penilaian otentik merupakan sistem penilaian yang dilakukan untuk, (1) mengukur pengetahuan dan keterampilan siswa, (2) penilaian produk (kinerja), (3) tugas-tugas yang relevan dan kontekstual, (4) menilai dengan berbagai cara dan dari berbagai sumber, (5) mengukur pengetahuan dan keterampilan siswa, (6) mempersyaratkan penerapan pengetahuan dan keterampilan; dan (7) proses dan produk kedua-duanya dapat diukur.

Dengan demikian penilaian otentik merupakan penilaian yang lebih komprehensif dibandingkan dengan penilaian standar (standardized test).

Agar asesmen otentik dapat dilakukan dengan baik, perlu dilakukan langkah-langkah pengembangan instrument penilaian. Haryono (2009) menyatakan, pengembangan sistem penilaian otentik dapat dilakukan melalui beberapa langkah, antara lain:

1) Mengkaji standar kompetensi

Standar ini telah tercantum pada kurikulum yang menggambarkan kemampuan minimal yang harus dimiliki oleh lulusan dalam setiap mata pelajaran. Standar ini memiliki implikasi yang sangat signifikan dalam perencanaan, implementasi dan pengelolaan penilaian.

2) Mengkaji kompetensi dasar

Kompetensi dasar adalah kemampuan minimal yang harus dimiliki siswa pada bahasan tertentu.

Untuk itu pada langkah ini guru sudah mulai memikirkan materi yang harus diberikan pada siswa agar siswa dapat memiliki kompetensi yang telah dirumuskan. 
3) Pengembangan silabus penilaian

Pengembangan silabus penilaian mencakup indikator, jenis tagihan, bentuk, ranah penilaian dan jadwal kegiatan penilaian dalam satu semester. Kegiatan ini akan lebih baik jika dilakukan bersamaan dengan pengembangan silabus materi pembelajaran.

4) Proses implementasi

Proses implementasi menggunakan berbagai teknik penilaian seperti yang telah direncanakan dan pelaksanaan sesuai jadwal yang telah diinformasikan pada siswa.

5) Pencatatan, pengolahan, tindak lanjut dan pelaporan

Semua hasil penilaian diupayakan untuk selalu terdokumentasikan secara baik. Tindak lanjut dari hasil penilaian laporan dapat berupa pengayaan atau remedi. Dari langkah-langkah di atas jelas bahwa asesmen otentik dikembangkan dari analisis standar kompetensi dan kompetensi dasar yang selanjutnya dikembangkan dalam bentuk silabus penilaian. Hasil pengembangan silabus ini lalu dimplementasikan dalam proses pembelajaran, kemudian diolah dan hasilnya digunakan untuk keperluan remedi dan pengayaan.

Moon (2005) menyatakan bahwa penilaian otentik selalu memberi kesempatan pada siswa untuk menunjukkan pengetahuan dan skillnya dengan baik. Penilaian otentik menurut Moon memiliki karakteristik sebagai berikut; (1) fokus pada materi yang penting, ide-ide besar atau kecapan-kecakapan khusus, (2) merupakan penilaian yang mendalam, (3) mudah dilakukan di kelas atau di lingkungan sekolah, (4) menekankan pada kualitas produk atau kinerja dari pada jawaban tunggal, (5) dapat mengembangkan kekuatan dan penguasaan materi pembelajaran pada siswa, (6) memiliki kriteria yang sudah diketahui, dimengerti dan dinegosiasi oleh siswa dan guru sebelum penilaian dimulai, (7) menyediakan banyak cara yang memungkinkan siswa dapat menunjukkan bahwa ia telah memenuhi kriteria yang telah ditetapkan; dan (8) pemberian skor penilaian didasarkan pada esensi tugas. Selanjutnya Moon menyatakan bahwa penelitian yang dilakukannya telah membuktikan bahwa pengembangan penilaian otentik di sekolah telah mendapat respon yang positif baik oleh guru maupun siswa. Hasil penilaian otentik lebih dapat memberikan informasi hasil belajar yang konsisten dibanding dengan teknik penilaian yang tradisional (paper and pencil test).

Jenis penilaian otentik yang berkembang dalam dunia pendidikan, khususnya pembelajaran bahasa Inggris adalah performance assessment, portfolio, project, dan demonstration. Dari jenis penilaian otentik ini performance assessment adalah yang paling sering digunakan guru bahasa Inggris. Untuk mendapatkan pengukuran yang objektif, diperlukan rubrik penilaian yang berisi pedoman pemberian skor/nilai dan bagaimana menentukan skor akhir untuk penilaian yang bersifat kuantitatif.

\section{B. METODE PENELITIAN}

Penelitian termasuk jenis penelitian deskriptif kualitatif yaitu menggambarkan fenomena yang terjadi di sekolah. Penelitian deskriptif mencakup pengumpulan data untuk menjawab pertanyaan penelitian menyangkut kondisi terkini subjek penelitian (Gay, 1992). Penelitian ini juga dikategorikan penelitian kualitatif karena memahami manusia dan perilakunya (Burns, 1995), yaitu bagaimana guru mengimplementasikan penilaian otentik dalam pembelajaran. Penelitian ini berbentuk penelitian deskriptif kualitatif karena tujuan penelitian adalah mengidentifikasi, mendeskripsikan, dan menjelaskan implementasi authentic assessment dalam pembelajaran bahasa Inggris di dua SMPN (A dan B) Kota Padang.

Subjek penelitian ini adalah guru bahasa Inggris dan siswa yang sedang belajar bahasa Inggris dengan guru tersebut di dua SMPN Kota Padang. Guru bahasa Inggris dijadikan sebagai subjek penelitian karena merekalah yang merancang, mengimplementasikan dan menindak lanjuti penilaian otentik di sekolah mereka masing masing. Sementara siswa yang diajarnya juga dijadikan subjek penelitian untuk melakukan triangulasi terhadap data yang diperoleh dari guru mengenai implementasi penilaian otentik yang mereka lakukan. Guru bahasa Inggris yang dijadikan subjek penelitian ini adalah guru bahasa Inggris kelas VII dan VIII yang mengajar pada semester I tahun ajaran 2012/2013 di SMPN A dan SMPN B. Siswa yang dijadikan sebagai subjek penelitian ini diambilkan dari kelompok siswa yang nilai bahasa Inggrisnya tinggi dan kelompok siswa yang nilai bahasa Inggrisnya rendah pada masing-masing rombongan belajar (rombel). Masing-masing rombel diambil dua orang (1 orang siswa yang nilainya tinggi dan 1 orang siswa yang nilainya rendah). 
Data dikumpulkan dengan menggunakan kuesioner, interview dan telaah dokumen berupa RPP dan soal-soal latihan dan ujian untuk mengungkapkan bagaimana guru bahasa Inggris SMPN Kota Padang mengimplementasikan penilaian otentik. Data dikumpulkan pada akhir Semester 1 Tahun Ajaran 2012/2013 di mana subjek penelitian berada. Data dianalisis dengan menggunakan analisis deskriptif kualitatif dan kuantitatif, yaitu mendiskripsikan data berdasarkan pertanyaan penelitian yang diajukan. Analisis deskriptif kualitatif dilakukan terhadap respon guru dan siswa, serta hasil telaah dokumen dengan mejelaskan dalam bentuk kata-kata dan memaknainya. Analisis deskriptif kuantitatif dilakukan terhadap data yang dapat dikuantifikasikan berupa persentase terhadap jawaban responden guru dan siswa.

\section{TEMUAN PENELITIAN}

1. Kemampuan guru menyusun perangkat penilaian otentik

Kemampuan guru bahasa Inggris Kota Padang dalam menyusun perangkat penilaian otentik dapat dilihat pada Silabus dan RPP yang dibuat oleh guru bahasa Inggris SMPN Kota Padang dan ujian harian/tengah semester/akhir semester yang dibuat guru. Ada tiga ranah kemampuan guru yang akan dianalisis, yaitu kemampuan menilai kognitif, afektif, dan psikomotor.

\section{a. Penilaian Kognitif}

Penilaian kognitif berkaitan dengan kegiatan intelektual siswa yang mencakup pengetahuan, pemahaman, aplikasi, analisis, sintesis, dan evaluasi. Analisis terhadap Rencana Pelaksanaan Pembelajaran (RPP) yang dibuat oleh guru bahasa Inggris kelas VII SMPN A Padang dapat memperlihatkan bagaimana kemampuan guru menyusun perangkat penilaian otentik. Kemampuan guru tersebut dapat dilihat dalam merancang aktifitas pembelajaran dan asesmen yang dirancangnnya. Lihatlah tabel 3.

\section{Tabel 3: Aktifitas Pembelajaran dan Asesmen yang Dibuat Guru Bahasa Inggris}

\begin{tabular}{|c|c|c|c|}
\hline No & $\begin{array}{l}\text { Keterampilan } \\
\text { Bahasa }\end{array}$ & Aktivitas Pembelajaran & Asesmen \\
\hline 1. & $\begin{array}{l}\text { Mendengar } \\
\text { (Listening) }\end{array}$ & $\begin{array}{l}\text { 1. Tanya dan jawab berdasarkan materi } \\
\text { pembelajaran } \\
\text { 2. Diskusi vocabulary dan grammar } \\
\text { 3. Mendengar dialog } \\
\text { 4. Menjawab pertanyaan }\end{array}$ & $\begin{array}{l}\text { 1. Tes lisan } \\
\text { 2. Tes performan } \\
\text { 3. Tes tulis (fill in the blank, use negative form to } \\
\text { complete the entence) } \\
\text { 4. Response of instruction } \\
\text { 5. Questions of list equipment }\end{array}$ \\
\hline 2. & $\begin{array}{l}\text { Berbicara } \\
\text { (Speaking) }\end{array}$ & $\begin{array}{l}\text { 1. Tanya dan jawab berdasarkan materi } \\
\text { pembelajaran } \\
\text { 2. Mengulangi ungkapan } \\
\text { 3. Diskusi vocabulary } \\
\text { 4. Mendengar ungkapan } \\
\text { 5. Mempraktekkan ungkapan (expression) } \\
\text { 6. Menggunakan ungkapan }\end{array}$ & $\begin{array}{l}\text { 1. Tes lisan (bercerita tentang gambar) } \\
\text { 2. Tes performan (menampilkan dialog di depan } \\
\text { kelas, memberi instruksi kepada teman, } \\
\text { menyebutkan nama benda di laboratorium, } \\
\text { memberi ucapan selamat kepada teman) } \\
\text { 3. Mendengar ujaran dan meresponnya. } \\
\text { 4. Bermain peran (role play) }\end{array}$ \\
\hline 3. & $\begin{array}{l}\text { Membaca } \\
\text { (Reading) }\end{array}$ & $\begin{array}{l}\text { 1. Mendengar dan mengulang ucapan dan } \\
\text { intonasi yang benar } \\
\text { 2. Mengidentifikasi informasi berdasarkan teks } \\
\text { 3. Mendiskudikan vocabulary dan grammar } \\
\end{array}$ & $\begin{array}{l}\text { 1. Menjawab pertanyaan berdasarkan teks (lisan, } \\
\text { pilihan ganda) } \\
\text { 2. Melengkapi kalimat. }\end{array}$ \\
\hline 4. & $\begin{array}{l}\text { Menulis } \\
\text { (Writing) }\end{array}$ & $\begin{array}{l}\text { 1. Menulis teks singkat dalam kelompok } \\
\text { 2. Menulis teks singkat secara individual }\end{array}$ & $\begin{array}{l}\text { 1. Melengkapi kalimat } \\
\text { 2. Jumbled text } \\
\text { 3. Menulis } \\
\text { 4. Menjawab pertanyaan berdasarkan teks }\end{array}$ \\
\hline
\end{tabular}

Tabel 1 di atas menunjukkan bahwa secara umum aktifitas pembelajaran menggambarkan dapat dilaksanakannya penilaian otentik. Aktifitas pembelajaran bervariasi sesuai dengan keterampilan berbahasa yang dilatihkan. Asesmen yang diberikan menunjukkan bahwa guru melakukan asesmen otentik dan asesmen tradisional. Asesmen otentik yang dilakukan berupa tes performan, tes lisan, bermain peran (role play), menjawab pertanyaan lisan, dan menulis. Asesmen tradisional berupa tes tulis dan melengkapi kalimat.

Untuk merealisasikan asesmen otentik, diperlukan rubrik asesmen. Rubrik asesmen dapat dibuat guru dari yang paling sederhana sampai kepada yang kompleks. Berikut ini adalah rubrik 
asesmen sederhana sebagai dasar untuk memberikan angka pada hasil belajar siswa yang dibuat oleh guru kelas VII SMPN A Padang.

Tabel 4: Rubrik Asesmen Kelas VII SMPN A Padang

\begin{tabular}{|l|l|c|c|}
\hline No. & \multicolumn{1}{|c|}{ Asesmen } & Score & Max Score \\
\hline 1. & Listening Comprehension & & 100 \\
\hline 2. & Speaking & 40 & 100 \\
& $-\quad$ Pronunciation & 30 & \\
& $-\quad$ Spelling and Grammar & 30 & \\
& $-\quad$ Content & & 100 \\
\hline 3. & Reading & 50 & \\
& $-\quad$ Understanding the instruction & 50 & \\
& $-\quad$ Doing the actions & 40 & \\
\hline 4. & Writing & 30 & \\
& $-\quad$ Content & 30 & \\
& $-\quad$ Grammar and spelling & & \\
& $-\quad$ Vocabulary & \\
\hline
\end{tabular}

Rubrik asesmen di atas berupa gabungan empat keterampilan berbahasa, yaitu listening, speaking, reading, dan writing. Penilaian listening compehension tidak menggunakan indikator, hanya dinyatakan skor maksimum 100. Sementara speaking mempunyai tiga indikator (pronunciation, spelling and grammar, dan content), reading mempunyai dua indikator (understanding the instruction, dan doing the actions), dan writing mempunyai tiga indikator (content, grammar and spelling, dan vocabulary). Keterampilan speaking memberikan bobot besar pada pronunciation, dan keterampilan writing menekankan pada content.

Untuk penilaian otentik, semakin detail unsur keterampilan yang dinilai, dengan kriteria pemberian skor yang juga detail dan jelas, semakin akurat penilaian yang diberikan terhadap keterampilan berbahasa siswa. Oleh karena itu penilaian otentik yang baik berisi indikator penilaian dan sistim pemberian skor, mulai dari skor terendah sampai skor tertinggi. Skor penilaian dapat menggunakan skala $10(0-10)$, skala $100(0-100)$, skala $4(0-4)$ dan skala $5(0-5)$, tergantung pada sistem pemberian nilai pada suatu sekolah. Sebaiknya sekolah memberikan skor sesuai dengan sistem pemberian nilai yang berlaku di sekolah tersebut.

Berikut ini dapat kita lihat rubrik yang dibuat guru SMPN Kota Padang untuk masing-masing keterampilan dari empat keterampilan berbahasa (Listening, Speaking, Reading, dan Writing) serta penilaian afektif.

\section{1) Penilaian otentik untuk Listening}

Berikut ini adalah contoh penilaian otentik untuk keterampilan listening. Ada tiga tugas yang diberikan guru untuk menilai kemampuan listening siswa, yaitu:

a) Listen to the dialogues and answer the questions. (Dengar dialog berikut ini dan kemudian jawab pertanyaan)

b) Listen to the sentences and write down on your book then arrange them to become a good dialogue. (Dengar kalimat-kalimat berikut ini dan tulis di buku anda, kemudian susun kalimat tersebut menjadi suatu dialog)

c) Say a statement and ask your friend to respond it by using the expression. (Ujarkan sebuah kalimat dan minta teman anda meresponnya dengan menggunakan ungkapan yang sesuai).

Ketiga tugas di atas dinilai dengan menggunakan rubrik penilaian berikut ini.

Tabel 5: Rubrik untuk Listening Kelas VII and VIII SMPN A dan SMPN B Padang

\begin{tabular}{|l|l|c|}
\hline \multicolumn{1}{|c|}{ No } & \multicolumn{1}{|c|}{ Description } & Score \\
\hline Task 1 and 2 & Correct answer & 1 \\
& Incorrect answer/no response & 0 \\
\hline Task 3 & Accurate grammar and content & 3 \\
& Accurate content, inaccurate grammar & 2 \\
& Inaccurate grammar and content & 1 \\
& No response & 0 \\
\hline
\end{tabular}

Berdasarkan tugas yang diberikan dan rubrik penilaian yang dibuat guru, terlihat bahwa tidak semua tugas memerlukan rubrik penilaian.Tugas 1 dan 2 hanya menilai jawaban siswa benar atau salah, 
maka penilaiannya hanya berupa skor betul berapa harus dinilai dan skor salah berapa harus dinilai. Sementara tugas 3 dan rubriknya lebih cocok untuk penilaian speaking atau integrasi speaking dan listening, jadi bukan hanya menilai kemampuan listening.

Rubrik penilaian ini tidak menjelaskan makna 0, 1, 2, 3 pada kolom score. Bagaimana memindahkan sistem score ini menjadi score puluhan (0-10) atau ratusan (0-100). Dalam scoring guide dinyatakan bahwa maksimum score untuk masing-masing task adalah 10. Jadi, diperlukan penjelasan bagaimana mengubah skor 0-3 menjadi 0-10.

\section{2) Penilaian otentik untuk speaking}

Berikut ini adalah contoh rubrik speaking yang dibuat oleh guru kelas VII SMPN A Padang. Rubrik ini hanya berisi empat komponen penilaian speaking, yaitu content, pronunciation, fluency, dan performance. Tugas yang akan dinilai dengan rubrik ini adalah "Tell about their poster to the class" (menceritakan gambar poster kepada teman-teman di kelas).

Table 6: Rubrik Penilaian Speaking Kelas VII SMPN A Padang

\begin{tabular}{|l|l|l|l|}
\hline Content & Pronunciation & Fluency & Performance \\
\hline & & & \\
\hline
\end{tabular}

Rubrik ini terlalu umum, tidak menjelaskan bagaimana cara memberi skor untuk masing-masing komponen dan juga tidak menjelaskan bagaimana mendapatkan skor akhir siswa.

Guru bahasa Inggris kelas VII SMPN B Padang menggunakan rubrik yang berbeda untuk menilai kemampuan berbicara siswa dibandingkan rubrik yang dibuat guru SMPN A Padang. Lihatlah tabel 7 berikut ini.

\section{Tabel 7: Rubrik Penilaian untuk Speaking Kelas VII SMPN B Padang}

\begin{tabular}{|l|c|l|}
\hline \multicolumn{1}{|c|}{ Aspek } & Skor & \multicolumn{1}{c|}{ Uraian } \\
\hline \multirow{4}{*}{ Ucapan } & 3 & Benar semua, sesuai dengan standar ucapan yang berlaku. \\
\cline { 2 - 3 } & 2 & Hampir semua benar dengan dua, tiga kata kurang tepat. \\
\cline { 2 - 3 } & 1 & Banyak membuat kesalahan. \\
\cline { 2 - 3 } & 3 & Benar semua, sesuai dengan aturan yang berlaku. \\
\cline { 2 - 3 } & 2 & Hampir semua benar dengan beberapa yang kurang tepat. \\
\hline Intonasi & 1 & Banyak yang kurang tepat. \\
\cline { 2 - 3 } & 2 & Benar semua, sesuai dengan aturan yang berlaku. \\
\cline { 2 - 3 } & 1 & Benar dengan satu atau dua intonasi kurang pas. \\
\hline Kelancaran & 3 & Lancar tanpa hambatan. \\
\cline { 2 - 3 } & 2 & Lancar dengan sesekali ragu. \\
\cline { 2 - 3 } & 1 & Tersendat sendat. \\
\hline
\end{tabular}

Pada tabel 7 di atas terlihat bahwa rubrik penilaian speaking sudah mempunyai gradasi skor, mulai dari yang terendah 1 dan yang tertinggi 3. Nilai terendah diberikan untuk ucapan yang banyak kesalahan, tekanan banyak yang kurang tepat, banyak intonasi yang kurang jelas, dan tersendatsendat. Sedangkan nilai tertinggi diberikan untuk ucapan, tekanan, dan intonasi yang benar sesuai dengan standar ucapan yang berlaku dan berbicara dengan lancar tanpa hambatan. Namun, tidak ada penjelasan bagaimana mengubah skor 1-3 menjadi nilai puluhan (0-10) atau ratusan (0-100).

Rubrik penilaian speaking berikut ini lebih lengkap. Rubrik yang mereka buat lebih detail dan pensekorannya juga lebih detail dan jelas mulai dari skor 1 (very poor) sampai kepada skor 5 (excellent). Lihatlah contoh berikut ini. Ada enam aspek yang dinilai dalam berbicara, yaitu fluency, accuracy, clarity, intonation, volume, dan content. Tugas yang diberikan kepada siswa untuk dinilai dengan rubrik penilaian ini adalah "Have a dialogue with your classmate based on the following situations. Use the expressions of offering, accepting, and refusing something." (Lakukan dialog dengan teman sekelas anda berdasarkan situasi berikut ini. Gunakan ungkapan-ungkapan offering, accepting dan refusing something). 
Table 8: Rubrik Penilaian Speaking kelas VII SMPN B Padang

\begin{tabular}{|c|c|c|c|c|c|c|}
\hline \multirow[t]{2}{*}{ No } & \multirow{2}{*}{$\begin{array}{l}\text { Aspect } \\
\text { Graded }\end{array}$} & \multirow{2}{*}{ Excellent } & \multirow{2}{*}{$\begin{array}{c}4 \\
\text { Good }\end{array}$} & \multirow{2}{*}{$\begin{array}{c}3 \\
\text { Fair }\end{array}$} & \multirow{2}{*}{$\frac{2}{\text { Poor }}$} & \multirow{2}{*}{$\frac{1}{\text { Very Poor }}$} \\
\hline & & & & & & \\
\hline 1. & Fluency & $\begin{array}{l}\text { Very smooth } \\
\text { with no pauses }\end{array}$ & $\begin{array}{l}\text { Smooth enough } \\
\text { with very few } \\
\text { pauses }\end{array}$ & $\begin{array}{l}\text { Normal speed } \\
\text { with few pauses }\end{array}$ & $\begin{array}{l}\text { Slow pace with } \\
\text { frequent pauses }\end{array}$ & $\begin{array}{l}\text { The pace is very } \\
\text { slow with too many } \\
\text { pauses }\end{array}$ \\
\hline 2. & Accuracy & 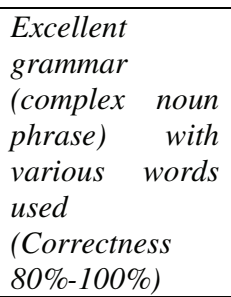 & $\begin{array}{l}\text { Very few } \\
\text { mistakes in } \\
\text { grammar with } \\
\text { enough variety } \\
\text { of vocabulary } \\
\text { (Correctness } \\
61 \%-80 \%)\end{array}$ & $\begin{array}{l}\text { Few mistakes in } \\
\text { grammar with } \\
\text { very sufficient } \\
\text { vocabulary but } \\
\text { still } \\
\text { understandable } \\
\text { (Correctness } \\
41 \%-60 \%)\end{array}$ & $\begin{array}{l}\text { Several mistakes in } \\
\text { grammar with very } \\
\text { limited vocabulary } \\
\text { but still } \\
\text { understandable } \\
\text { (Correctness } 41 \%- \\
60 \%)\end{array}$ & $\begin{array}{l}\text { Very poor diction } \\
\text { and grammar whivh } \\
\text { lead to } \\
\text { misunderstanding } \\
\text { (correctness 0\%- } \\
39 \%)\end{array}$ \\
\hline 3. & Clarity & $\begin{array}{l}\text { Very clear } \\
\text { articulation } \\
\text { with good } \\
\text { pronunciation }\end{array}$ & $\begin{array}{l}\text { Good } \\
\text { pronunciation } \\
\text { with very few } \\
\text { mistakes and } \\
\text { clear } \\
\text { articulation }\end{array}$ & $\begin{array}{l}\text { Few mistakes in } \\
\text { pronunciation } \\
\text { with inconsistent } \\
\text { articulation but } \\
\text { still } \\
\text { understandable }\end{array}$ & $\begin{array}{l}\text { Several mistakes in } \\
\text { pronunciation with } \\
\text { inconsistent } \\
\text { articulation which } \\
\text { lead to difficult } \\
\text { understanding }\end{array}$ & $\begin{array}{l}\text { Many mistakes in } \\
\text { pronunciation with } \\
\text { unclear articulation } \\
\text { and difficult to } \\
\text { understand. }\end{array}$ \\
\hline 4. & Inton & $\begin{array}{l}\text { Correct } \\
\text { intonation/tone } \\
\text { for the words/ } \\
\text { phrases/ } \\
\text { sentences with } \\
\text { leadrar to } \\
\text { appropriate the } \\
\text { intended } \\
\text { meaning }\end{array}$ & $\begin{array}{l}\text { Very few } \\
\text { mistakes in } \\
\text { intonation/tone } \\
\text { for the words/ } \\
\text { phrases/sentenc } \\
\text { es with lead to } \\
\text { appropriate the } \\
\text { intended } \\
\text { meaning }\end{array}$ & $\begin{array}{l}\text { Few mistakes in } \\
\text { intonation/tone } \\
\text { which interfere } \\
\text { the intended } \\
\text { meaning }\end{array}$ & $\begin{array}{l}\text { Several mistakes in } \\
\text { intonation/tone } \\
\text { which lead to } \\
\text { misunderstanding } \\
\text { of the intended } \\
\text { meaning }\end{array}$ & $\begin{array}{l}\text { No difference of } \\
\text { intonation/tone for } \\
\text { the words/ } \\
\text { phrases/sentences } \\
\text { which lead to } \\
\text { misunderstanding of } \\
\text { the intended } \\
\text { meaning }\end{array}$ \\
\hline 5. & Volume & $\begin{array}{l}\text { Speak very } \\
\text { loudly that the } \\
\text { audience in the } \\
\text { class can hear }\end{array}$ & $\begin{array}{l}\text { Speak loudly } \\
\text { that most of the } \\
\text { audience in the } \\
\text { class can hear }\end{array}$ & $\begin{array}{l}\text { Only audience } \\
\text { from the middle } \\
\text { to the front row } \\
\text { can hear the } \\
\text { voice }\end{array}$ & $\begin{array}{l}\text { Speak softly that } \\
\text { only very few the } \\
\text { audience can hear } \\
\text { clearly }\end{array}$ & $\begin{array}{l}\text { Speak very softly } \\
\text { that the audience } \\
\text { cannot hear }\end{array}$ \\
\hline 6. & Content & $\begin{array}{l}\text { The content of } \\
\text { the presentation } \\
\text { contains very } \\
\text { complete } \\
\text { information } \\
\text { (physical } \\
\text { description) } \\
\text { about the } \\
\text { person being } \\
\text { described and } \\
\text { meet the } \\
\text { purpose of the } \\
\text { function of the } \\
\text { spoken text }\end{array}$ & $\begin{array}{l}\text { The content of } \\
\text { the presentation } \\
\text { contains } \\
\text { complete } \\
\text { information } \\
\text { (physical } \\
\text { description) } \\
\text { about the } \\
\text { person being } \\
\text { described and } \\
\text { meet the } \\
\text { purpose of the } \\
\text { function of the } \\
\text { spoken text }\end{array}$ & $\begin{array}{l}\text { The content of } \\
\text { the presentation } \\
\text { contains } \\
\text { sufficient } \\
\text { information } \\
\text { (physical } \\
\text { description) } \\
\text { about the } \\
\text { person being } \\
\text { described and } \\
\text { fairly meet the } \\
\text { purpose of the } \\
\text { function of the } \\
\text { spoken text }\end{array}$ & $\begin{array}{l}\text { The content of the } \\
\text { presentation } \\
\text { contains little } \\
\text { information } \\
\text { (physical } \\
\text { description) about } \\
\text { the person being } \\
\text { described and } \\
\text { almost does not } \\
\text { meet the purpose } \\
\text { of the function of } \\
\text { the spoken text }\end{array}$ & $\begin{array}{l}\text { The content of the } \\
\text { presentation } \\
\text { contains very little } \\
\text { information } \\
\text { (physical } \\
\text { description) about } \\
\text { the person being } \\
\text { described and does } \\
\text { not meet the } \\
\text { purpose of the } \\
\text { function of the } \\
\text { spoken text }\end{array}$ \\
\hline
\end{tabular}

Rubrik ini sangat bagus, tetapi ini lebih cocok untuk wacana yang lebih luas, bukan untuk menilai dialog. Oleh karena itu, guru harus bisa menentukan rubrik mana yang cocok untuk menilai keterampilan bahasa tertentu.

Rubrik penilaian berikut ini lebih sederhana dibandingkan dengan rubrik penilaian terdahulu. Rubrik ini khusus digunakan untuk menilai teks fungsional pendek. Ada empat aspek yang dinilai, yaitu grammar dan vocabulary, manajemen wacana teks fungsional pendek, kejelasan makna, dan hubungan antar gagasan. Pedoman pensekorannya cukup jelas dan menggambarkan gradasi kemampuan siswa. Lihatlah pedoman pensekoran speaking yang dibuat oleh guru ke VIII SMPN B Padang berikut ini.

Tabel 9: Pedoman Pensekoran Speaking (Teks Fungsional Pendek)

\begin{tabular}{|l|l|c|}
\hline No & \multicolumn{1}{|c|}{ Aspek yang dinilai } & Skor \\
\hline 1. & $\begin{array}{c}\text { Grammar dan Vocabulary (Leksikogramatika) } \\
\text { - Menggunakan tata bahasa yang benar dan kosa kata yang tepat } \\
\text { - Menggunakan tata bahasa dan kosa kata yang terkadang kurang tepat, tetapi tidak } \\
\text { mempengaruhi makna }\end{array}$ & 3 \\
\hline
\end{tabular}




\begin{tabular}{|c|c|c|}
\hline & $\begin{array}{l}\text { - Menggunakan tata bahasa dan kosa kata yang kurang tepat dan mempengaruhi makna } \\
\text { - Tata bahasa dan kosa kata yang sulit/tidak dapat dimengerti } \\
\text { - Tulisan tidak berkembang }\end{array}$ & $\begin{array}{l}2 \\
1 \\
0\end{array}$ \\
\hline 2. & $\begin{array}{l}\text { Manajemen Wacana } \\
\text { - Melakukan dan merespon tindak tutur dengan tepat (logis) dalam bahasa lisan. } \\
\text { - } \quad \text { Selakukan dan merespon tindak tutur meskipun sesekali salah paham. } \\
\text { - Tidak mampu memahami dan merespon tindak tutur sederhana. } \\
\text { - Hanya memproduksi kata-kata yang tidak membentuk teks. }\end{array}$ & $\begin{array}{l}4 \\
3 \\
2 \\
1 \\
0\end{array}$ \\
\hline 3. & $\begin{array}{l}\text { Ucapan dan Intonasi } \\
\text { - Ucapan dan intonasi sangat jelas mendekati penutur asli } \\
\text { - Ucapan dan intonasi jelas meskipun terdapat aksen bahasa pertama. } \\
\text { - Ucapan dan intonasi kurang jelas dan mempengaruhi makna. } \\
\text { - Ucapan dan intonasi tidak jelas dan menghilangkan sejumlah makna. } \\
\text { - Ucapan dan intonasi tidak mampu mengungkapkan makna. }\end{array}$ & $\begin{array}{l}4 \\
3 \\
2 \\
1 \\
0 \\
\end{array}$ \\
\hline 4. & $\begin{array}{l}\text { Komunikasi Interaktif (strategi berkomunikasi) } \\
\text { - Percaya diri dan lancar dalam berbicara dan mampu mengoreksi diri jika membuat kesalahan. } \\
\text { - } \quad \text { Percaya diri, meskipun terkadang minta pengulangan dan menunjukkan keraguan. } \\
\text { - } \quad \text { Sebih banyak merespon daripada berinisiatif. } \\
\text { - Tiajak berbicara meskipun sudah dipancing. }\end{array}$ & $\begin{array}{l}4 \\
3 \\
2 \\
1 \\
0\end{array}$ \\
\hline
\end{tabular}

\section{The Range of Score}

$85-100$

$70-84$

$55-74$

$<54$

The highest score $=16$

$$
\begin{aligned}
& \text { Qualitative Score } \\
& \text { A }=\text { Excellent } \\
& \text { B }=\text { Very Good } \\
& \text { C }=\text { Fair } \\
& \text { D }=\text { Poor }
\end{aligned}
$$

Kalau Satria Negara memperoleh skor 10, maka nilai Satria Negara adalah: $\underline{10} \times 10=6,25$. Ini berarti bahwa Satria Negara mendapat nilai C (Fair) 16

Rubrik di atas adalah yang paling lengkap dibuat oleh guru, yaitu dengan jelas mengemukakan bagaimana menilai kemampuan speaking dengan disertai pedoman pensekoran dan penentuan nilai per-individu.

\section{3) Penilaian Otentik untuk Reading}

Kemampuan membaca (reading) adalah kemampuan menggali informasi tertulis. Komponen utama yang diukur adalah kemampuan memahami isi bacaan dan kemampuan memahami makna kata dan makna kalimat. Pembelajaran reading di kelas dapat berupa reading aloud dan reading comprehension. Reading aloud (membaca keras) adalah kemampuan membaca dengan penekanan pada intonasi, pelafalan kata, di samping kemampuan memahami isi wacana. Reading comprehension menekankan pada pemahaman isi wacana baik secara umum maupun secara detail.

Berikut ini adalah rubrik penilaian yang digunakan oleh guru bahasa Inggris SMPN A Padang. Ada dua komponen yang diukur dalam penilaian ini, yaitu grammar dan content. Lihatlah tabel 10 berikut ini.

\section{Table 10: Rubrik Penilaian Reading Kelas VII dan VIII SMPN A dan B Padang}

\begin{tabular}{|c|l|c|}
\hline No & \multicolumn{1}{|c|}{ Description } & Score \\
\hline 1. & Accurate grammar and content & 3 \\
\hline 2. & Accurate content, inaccurate grammar & 2 \\
\hline 3. & Inaccurate grammar and content & 1 \\
\hline 4. & No response & 0 \\
\hline
\end{tabular}

Pada tabel di atas dapat dilihat bahwa rubrik penilaian reading mempunyai dua indikator, yaitu grammar dan content. Kedua indikator ini dilihat keakuratan dan ketidak akuratannya. Kedua 
komponen ini tidak terkait dengan upaya mencari makna dalam suatu bacaan. Jadi, rubrik penilaian ini sebetulnya tidak cocok untuk menilai kemampuan membaca siswa.

Pada pembahasan sebelumnya dapat dilihat bahwa rubrik ini juga digunakan untuk menilai listening. Sebagaimana dinyatakan di atas, rubrik ini juga tidak sesuai untuk menilai kemampuan listening, tetapi lebih tepat menilai speaking atau writing.

\section{4) Penilaian otentik untuk writing}

Kemampuan menulis (writing) adalah kemampuan menyampaikan gagasan dalam bentuk tertulis. Seseorang bisa menulis apabila dia minimal memiliki tiga kemampuan, yaitu gagasan (content), kosa kata yang memadai (vocabulary) dan mempunyai kemampuan menulis kalimat dengan benar (grammar). Jadi, minimal tiga kemampuan dasar ini harus dimiliki oleh seorang siswa. Di samping tiga hal tersebut suatu tulisan harus mempunyai kohesi dan koherensi yang baik.

Berikut ini akan dibandingkan beberapa rubrik penilaian menulis yang dibuat oleh guru bahasa Inggris SMPN Kota Padang. Tabel 11 adalah scoring rubrics yang dibuat oleh guru bahasa Inggris kelas VII SMPN A Padang.

Tabel 11: Rubrik Penilaian WritingKelas VII SMPN A Padang

\begin{tabular}{|l|l|c|}
\hline \multicolumn{1}{|c|}{ No } & \multicolumn{1}{|c|}{ Description } & Score \\
\hline 1. & Accurate grammar and content & 3 \\
\hline 2. & Accurate content, inaccurate grammar & 2 \\
\hline 3. & Inaccurate content, accurate grammar & 1 \\
\hline
\end{tabular}

$\begin{array}{lll}\text { Keterangan: } & \text { Score 3 } & : 91-100 \\ & \text { Score 2 } & : 81-90 \\ & \text { Score 1 } & : 70-80\end{array}$

Rubrik penilaian pada tabel 11 hanya berisi dua indikator, yaitu grammar dan content. Keduanya dilihat dari sisi keakuratan dan ketidakakuratan penggunaan grammar dan content. Rubrik penilaian ini disertai pedoman pengalihannya menjadi nilai 0-100. Tetapi, skor terendah diberikan 70. Ini barangkali perlu peninjauan, karena rentangan nilai biasanya dari 0 sampai 100 . Jadi, pensekoran ini tidak memungkinkan penilai memberi nilai $0-69$, pada hal nilai dalam rentangan itu masih wajar diberikan kepada siswa.

Rubrik penilaian berikut ini lebih detail dalam komponen penilaiannya. Guru memasukkan komponen coherence, spelling, dan vocabulary dalam rubrik penilaian yang dibuatnya. Di samping itu, skornya juga lebih rasional, yaitu memulai dari nilai 0-100. Lihatlah rubrik penilaian yang dibuat oleh guru kelas VII SMPN A Padang berikut ini.

\section{Table 12: Rubrik Penilaian WritingKelas VII SMPN A Padang}

\begin{tabular}{|c|l|c|}
\hline No & \multicolumn{1}{|c|}{ Features } & Score \\
\hline $5-7$ & 1. Content & $0-50$ \\
\hline & 2. Coherence & $0-20$ \\
\hline & 3. Spelling & $0-10$ \\
\hline & 4. Grammar & $0-10$ \\
\hline & 5. Vocabulary & $0-10$ \\
\hline & Total & $\mathbf{1 0 0}$ \\
\hline
\end{tabular}

Rubrik penilaian di atas akan lebih baik kalau dilengkapi dengan gradasi kemampuan masing-masing komponen content, coherence, spelling, grammar, dan vocabulary dengan membuat rubrik yang terukur.

Berikut ini adalah rubrik penilaian yang lebih detail yang juga dibuat oleh guru bahasa Inggris kelas VII SMPN A Padang. Rubrik ini berisi dua indikator utama, accuracy dan content. Accuracy mencakup grammar, vocabulary dan spelling. Content mencakup coherency/unity dan content. Masing-masing sub-indikator diberi bobot yang berbeda, dengan bobot terbesar diberikan untuk content. Setelah itu diberikan pedoman gradasi pensekoran mulai dari yang terendah sampai yang 
tertinggi. Rubrik asesmen dimaksud, berupa "product assessment" untuk keterampilan menulis dapat dilihat pada tabel 11 berikut.

Tabel 13: Instrumen Product Assessment Kelas VII SMPN A Padang

\begin{tabular}{|c|c|c|c|c|c|}
\hline \multirow[t]{9}{*}{1} & \multirow[t]{9}{*}{ Accuracy } & \multirow[t]{3}{*}{ Grammar } & \multirow[t]{3}{*}{20} & $16-20$ & Tata bahasa tepat \\
\hline & & & & $10-15$ & Tata bahasa kurang tepat tetapi tidak mempengaruhi makna \\
\hline & & & & $<10$ & Tata bahasa kurang tepat dan mempengaruhi makna \\
\hline & & \multirow[t]{3}{*}{ Vocabulary } & \multirow[t]{3}{*}{20} & $16-20$ & Pilihan kosa kata Tepat \\
\hline & & & & $10-15$ & Pilihan kosa kata kurang tepat tetapi tidak mempengaruhi makna \\
\hline & & & & $<10$ & Pilihan kosa kata kurang tepat dan mempengaruhi makna \\
\hline & & \multirow[t]{3}{*}{ Spelling } & \multirow[t]{3}{*}{15} & $11-15$ & Penulisan secara umum tepat \\
\hline & & & & $6-10$ & Penulisan kurang tepat tetapi tidak mempengaruhi makna \\
\hline & & & & $<5$ & Penulisan kurang tepat dan mempengaruhi makna \\
\hline \multirow[t]{6}{*}{2.} & \multirow[t]{6}{*}{ Content } & \multirow{3}{*}{$\begin{array}{l}\text { Coherency/ } \\
\text { Unity }\end{array}$} & \multirow[t]{3}{*}{15} & $11-15$ & Hubungan antar gagasan jelas \\
\hline & & & & $6-10$ & $\begin{array}{l}\text { Hubungan antar gagasan kurang jelas tetapi tidak menghilangkan } \\
\text { makna }\end{array}$ \\
\hline & & & & $<5$ & Hubungan antar gagasan tidak jelas dan menghilangkan makna \\
\hline & & \multirow[t]{3}{*}{ Content } & \multirow[t]{3}{*}{30} & $20-30$ & Mengungkapkan makna dengan jelas \\
\hline & & & & $11-20$ & Mengungkapkan makna tetapi kurang jelas \\
\hline & & & & $<10$ & Mengungkapkan makna secara tidak jelas dan kehilangan makna \\
\hline
\end{tabular}

Berikut ini adalah rubrik penilaian writing yang digunakan oleh guru bahasa Inggris Kelas VII SMPN A Padang. Rubrik penilaian ini hanya terdiri dari dua komponen, yaitu organization dan language. Kedua komponen ini diberi gradasi dengan skor terendah 30 dan skor tertinggi 100.

Tabel 14: Rubrik Penilaian Writing Kelas VII SMPN A Padang

\begin{tabular}{|l|l|l|l|}
\hline No & Range & \multicolumn{1}{c|}{ Organization } & \multicolumn{1}{c|}{ Language } \\
\hline 1. & $100-90$ & $\begin{array}{l}\text { The main components are included. The } \\
\text { details of message are well-organized. }\end{array}$ & $\begin{array}{l}\text { Excellent control of grammar } \\
\text { Excellent control of vocabulary } \\
\text { Excellent control of punctuation }\end{array}$ \\
\hline 2. & $89-70$ & $\begin{array}{l}\text { The main components are included. The } \\
\text { details of the message are fairly well- } \\
\text { organized. }\end{array}$ & $\begin{array}{l}\text { Good control of grammar } \\
\text { Good control of vocabulary } \\
\text { Good control of punctuation }\end{array}$ \\
\hline 3. & $69-50$ & $\begin{array}{l}\text { The main components are included. The } \\
\text { details are sometimes not organized. }\end{array}$ & $\begin{array}{l}\text { Good control of grammar Adequate } \\
\text { control of vocabulary } \\
\text { Lack control of punctuation }\end{array}$ \\
\hline 4. & $49-30$ & $\begin{array}{l}\text { One or two of the components are not } \\
\text { included. The details are not organized. }\end{array}$ & $\begin{array}{l}\text { Little control of grammar } \\
\text { Lack control of vocabulary } \\
\text { Poor control of punctuation }\end{array}$ \\
\hline
\end{tabular}

Rubrik penilaian ini cocok digunakan untuk menilai keterampilan menulis untuk tulisan pendek. Walaupun hanya ada dua komponen utama, tetapi rubriknya cukup lengkap. Untuk komponen organization mencakup komponen teks dan detil pesan/isi, sementara untuk komponen language mencakup grammar, vocabulary dan punctuation.

Berikut ini rubrik penilaian writing yang dibuat oleh guru Bahasa Inggris kelas VII SMPN B Padang. Berbeda dengan rubrik di atas yang hanya menggunakan dua komponen yaitu organization dan language, rubrik ini menggunakan tiga komponen, yaitu content, organization, dan language. Konten (isi) merupakan bagian penting dalam menulis, karena di sinilah keberadaan pesan atau ide yang ingin disampaikan kepada pembaca. Isi tulisan yang baik adalah apabila pesan yang ditulis dapat dipahami dengan gampang dan spesifik. Lihatlah tabel 15 berikut.

Tabel 15: Rubrik Penilaian Writing Kelas VII SMPN B Padang

\begin{tabular}{|l|c|l|l|l|}
\hline No & Range & \multicolumn{1}{c|}{ Content } & \multicolumn{1}{c|}{ Organization } & \multicolumn{1}{c|}{ Language } \\
\hline 1. & $100-90$ & $\begin{array}{l}\text { The purpose and the audience are } \\
\text { clearly stated. The message is complete } \\
\text { and can be easily understood and the } \\
\text { information is specific. }\end{array}$ & $\begin{array}{l}\text { The main components are } \\
\text { included. The details of } \\
\text { message are well-organized. }\end{array}$ & $\begin{array}{l}\text { Excellent control of grammar } \\
\text { Excellent control of vocabulary } \\
\text { Excellent control of punctuation }\end{array}$ \\
\hline 2. & $89-70$ & $\begin{array}{l}\text { The purpose and the audience are } \\
\text { clearly stated. The message is complete }\end{array}$ & $\begin{array}{l}\text { The main components are } \\
\text { included. The details of the }\end{array}$ & $\begin{array}{l}\text { Good control of grammar } \\
\text { Good control of vocabulary }\end{array}$ \\
\hline
\end{tabular}


ISLA-2 Proceeding of the International Seminar on Languages and Arts 2013 FBS Universitas Negeri Padang

\begin{tabular}{|l|l|l|l|l|}
\hline & & $\begin{array}{l}\text { and can be understood and the } \\
\text { information is specific. }\end{array}$ & $\begin{array}{l}\text { message are fairly well- } \\
\text { organized. }\end{array}$ & Good control of punctuation \\
\hline 3. & $69-50$ & $\begin{array}{l}\text { The purpose and the audience are } \\
\text { clearly stated. The message is sketchy } \\
\text { and is hard to read at times. }\end{array}$ & $\begin{array}{l}\text { The main components are } \\
\text { included. The details are } \\
\text { sometimes not organized. }\end{array}$ & $\begin{array}{l}\text { Good control of grammar Adequate } \\
\text { control of vocabulary } \\
\text { Lack control of punctuation }\end{array}$ \\
\hline 4. & $49-30$ & $\begin{array}{l}\text { The purpose and the audience may not } \\
\text { be stated. The message is hard to } \\
\text { understand and the information is vague. }\end{array}$ & $\begin{array}{l}\text { One or two of the } \\
\text { components are not } \\
\text { included. The details are not } \\
\text { organized. }\end{array}$ & $\begin{array}{l}\text { Little control of grammar } \\
\text { Lack control of vocabulary } \\
\text { Poor control of punctuation }\end{array}$ \\
\hline
\end{tabular}

Berikut ini adalah rubrik penilaian untuk teks fungsional pendek. Ada empat aspek yang dinilai, yaitu grammar dan vocabulary, manajemen wacana teks fungsional pendek, kejelasan makna, dan hubungan antar gagasan. Masing masing aspek diberi skor 0-4 sesuai dengan rubrik pada aspek yang dinilai. Lihatlah tabel 16 berikut.

Tabel 16: Pedoman Pensekoran Writing (Teks Fungsional Pendek) Kelas VIII SMPN B Padang

\begin{tabular}{|c|c|c|}
\hline No & Aspek yang dinilai & Skor \\
\hline 1. & $\begin{array}{l}\text { Grammar dan Vocabulary (Leksikogramatika) } \\
\text { - Menggunakan tatabahasa yang benar dan kosa kata yang tepat } \\
\text { - Menggunakan tata bahasa dan kosa kata yang terkadang kurang tepat, tetapi tidak } \\
\text { - Mempengaruhi makna } \\
\text { - Tata bahakana dan kosa kata yang sulit/tidak dapat dimengerti } \\
\text { - Tulisan tidak berkembang }\end{array}$ & $\begin{array}{l}2 \\
1 \\
0\end{array}$ \\
\hline 2. & $\begin{array}{l}\text { Manajemen Wacana Teks Fungsional Pendek } \\
\text { - Merealisasikan langkah retorika dengan tepat dalam ragam bahasa tulis sehingga tujuan } \\
\text { - } \quad \text { Memunikasi teks jelas (misalnya pengumuman, undangan, dll) } \\
\text { - } \text { kesalahan } \\
\text { - Menulis kata-kata, tetapi tujuan komunikatifnya sulit dimengerti } \\
\text { - } \quad \text { Henulis kata-kata, tetapi tujuan komunikatifnya tidak tersampaikan } \\
\text { - }\end{array}$ & $\begin{array}{l}2 \\
1 \\
0\end{array}$ \\
\hline 3. & $\begin{array}{l}\text { Kejelasan makna } \\
\text { - Mengungkapkan berbagai makna secara jelas dan efektif } \\
\text { - Mengungkapkan berbagai makna secara jelas } \\
\text { - Mengungkapkan makna, tetapi sesekali kurang jelas } \\
\text { - Mengungkapkan makna, tetapi sulit dipahami } \\
\end{array}$ & $\begin{array}{l}4 \\
3 \\
2 \\
1 \\
0\end{array}$ \\
\hline 4. & $\begin{array}{l}\text { Hubungan antar Gagasan } \\
\text { - Menunjukkan kelancaran hubungan antar gagasan } \\
\text { - Menunjukkan transisi hubungan antar gagasan } \\
\text { - Hubungan antar gagasan kurang jelas } \\
\text { - Hubungan antar gagasan kacau } \\
\text { - Gagal merealisasikan gagasan }\end{array}$ & $\begin{array}{l}4 \\
3 \\
2 \\
1 \\
0\end{array}$ \\
\hline
\end{tabular}

\section{The Range of Score}

$85-100$

$70-84$

$55-74$

$<54$

The highest score $=16$

Kalau Satria Negara memperoleh skor 10, maka nilai Satria Negara adalah:

$\underline{10} \times 10=6,25$. Ini berarti bahwa Satria Negara mendapat nilai C (Fair)

16

Pedoman pensekoran teks fungsional pendek berbeda dengan teks monolog. Perbedaan itu hanya pada aspek kedua, yaitu manajemen wacana. Pada teks fungsional pendek bagian ini berisi

$$
\begin{aligned}
& \text { Qualitative Score } \\
& \begin{array}{l}
\mathrm{A}=\text { Excellent } \\
\mathrm{B}=\text { Very Good } \\
\text { C }=\text { Fair } \\
\text { D }=\text { Poor }
\end{array}
\end{aligned}
$$


manajemen wacana teks fungsional pendek dengan aspek yang dinilai sesuai dengan wacana teks fungsional pendek, sementara pada teks monolog isinya adalah manajemen wacana genre.

Tabel 17: Pedoman Pensekoran Writing (Teks Monolog) Kelas VIII SMPN B Padang

\begin{tabular}{|c|c|c|}
\hline No & Aspek yang dinilai & Skor \\
\hline 1. & $\begin{array}{l}\text { Grammar dan Vocabulary (Leksikogramatika) } \\
\text { - } \quad \text { Menggunakan tata bahasa yang benar dan kosa kata yang tepat } \\
\text { - } \quad \text { Menggunakan tata bahasa dan kosa kata yang terkadang kurang } \\
\text { - } \quad \text { Mepat, tetapi tidak mempengaruhi makna } \\
\text { mempengaruhi makna } \\
\text { - Tata bahasa dan kosa kata yang sulit/tidak dapat dimengerti } \\
\text { - Tulisan tidak berkembang }\end{array}$ & $\begin{array}{l}4 \\
3 \\
2 \\
1 \\
0\end{array}$ \\
\hline 2. & $\begin{array}{l}\text { Manajemen Wacana Genre } \\
\text { - Memilih genre yang tepat untuk judul yang dipilih dengan struktur } \\
\text { - } \quad \text { Meks maksimal } \\
\text { - } \quad \text { Ptruktur teks miniman genre (tujuan komunikatif) tidak jelas } \\
\text { - } \quad \text { Tulisan tidak terstruktur } \\
\text { - } \quad \text { Menulis kata-kata secara acak, hampir tidak bermakna } \\
\end{array}$ & $\begin{array}{l}4 \\
3 \\
2 \\
1 \\
0\end{array}$ \\
\hline 3. & $\begin{array}{l}\text { Kejelasan makna } \\
\text { - } \quad \text { Mengungkapkan berbagai makna secara jelas dan efektif } \\
\text { - } \quad \text { Mengungkapkan berbagai makna secara jelas } \\
\text { - } \quad \text { Mengungkapkan makna, tetapi sesekali kurang jelas } \\
\text { - } \quad \text { Mengungkapkan makna, tetapi sulit dipahami } \\
\end{array}$ & $\begin{array}{l}4 \\
3 \\
2 \\
1 \\
0\end{array}$ \\
\hline 4. & $\begin{array}{l}\text { Hubungan Antar Gagasan } \\
\text { - } \quad \text { Menunjukkan kelancara hubungan antar gagasan } \\
\text { - } \quad \text { Menunjukkan transisi hubungan antar gagasan } \\
\text { - } \quad \text { Hubungan antar gagasan kurang jelas } \\
\text { - } \quad \text { Hubungan antar gagasan kacau } \\
\text { - } \quad \text { Gagal merealisasikan gagasan } \\
\end{array}$ & $\begin{array}{l}4 \\
3 \\
2 \\
1 \\
0\end{array}$ \\
\hline
\end{tabular}

\section{The Range of Score}

$85-100$

$70-84$

$55-74$

$<54$

The highest score $=16$

\section{Qualitative Score \\ $\mathrm{A}=$ Excellent \\ $\mathrm{B}=$ Very Good \\ $\mathrm{C}=$ Fair \\ $\mathrm{D}=$ Poor}

Kalau Satria Negara memperoleh skor 10, maka nilai Satria Negara adalah: $\underline{10} \times 10=6,25$. Ini berarti bahwa Satria Negara mendapat nilai C (Fair) 16

Dari beberapa model rubrik di atas dapat dilihat bahwa terdapat beberapa perbedaan penyusunan rubrik penilaian untuk menilai keterampilan menulis. Perbedaan tersebut dapat dilihat dari indikator yang digunakan. Ada yang indikatornya yang umum dan ada yang terperinci.

\section{b. Penilaian Afektif}

Penilaian afektif berkaitan dengan sikap siswa yang mencakup penerimaan (receiving), respon (responding) acuan nilai (valuing), organisasi, dan karakteristik. Penilaian afektif adalah menilai sikap dan keterlibatan siswa dalam kerja kelompok untuk merespon dan menggunakan ungkapanungkapan seperti meminta, memberi, menolak jasa/barang, mengakui, mengingkari fakta, dan meminta dan memberi pendapat. 
Penilaian afektif juga mempunyai beberapa aspek indikator, yaitu keaktifan, ketekunan, dan kerjasama. Rubrik penilaian afektif yang dibuat oleh guru bahasa Inggris SMPN A Padang dapat dilihat pada table 18 berikut ini.

Tabel 18: Rubrik Penilaian Afektif Kelas VII SMPN A Padang

\begin{tabular}{|l|l|l|l|l|l|l|l|}
\hline \multirow{2}{*}{ No } & Nama & \multicolumn{5}{|c|}{ ASPEK } & Jumlah \\
\cline { 3 - 7 } & & Keaktifan & Ketekunan & Kerjasama & & & Skor \\
\hline 1. & & & & & & & \\
\hline 2. & & & & & & & \\
\hline dst & & & & & & & \\
\hline
\end{tabular}

Pedoman Penskoran/Penilaian Afektif

\section{Skor}

4 : selalu

3 : biasanya

2 : kadang-kadang

1 : Jarang/tidak pernah

Skor tertinggi $=20$

Nilai : Jumlah skor perolehan

-

Jumlah skor tertinggi

Kalau Anita memperoleh skor 16, maka nilai Anita adalah: $\underline{16} \times 100=80$.Ini berarti bahwa Anita mendapat nilai Baik. 20

Di samping untuk menilai aspek sikap secara umum, rubrik penilaian afektif dapat juga digunakan untuk menilai aspek afektif pada masing-masing keterampilan berbahasa. Rubrik penilaian afektif untuk keterampilan speaking yang dilakukan oleh guru di SMPN B Padang dapat dilihat pada tabel 19 .

Penilaian afektif untuk speaking digunakan untuk menilai keterampilan sosial dan keterampilan personal. Penilai melakukan observasi terhadap prilaku siswa dan memberi tanda pada kolom penilaian apakah keterampilan itu ada atau tidak (identified or unidentified).

\section{Tabel 19: Rubrik Penilaian Afektif untuk Speaking Kelas VII SMPN B Padang}

Name/Student No:

\begin{tabular}{|l|l|l|}
\hline \multicolumn{1}{|c|}{ Personal and Social Skills } & Identified & Unidentified \\
\hline Ability to be responsible to their own task & & \\
\hline Ability to pay attention or listen to people speaking & & \\
\hline Ability to express asking, giving and refusing something & & \\
\hline Ability to appreciate others & & \\
\hline Ability to respond others & & \\
\hline
\end{tabular}

Aspek yang dinilai dalam penilaian afektif speaking berbeda dengan listening. Pada listening, aspek yang dinilai adalah seriousness, concentration, dan cooperation. Lihatlah rubrik penilaian afektif untuk listening berikut ini.

Tabel 20: Rubrik Penilaian Afektif untuk Listening Kelas VIII SMPN B Padang

\begin{tabular}{|l|l|l|l|l|c|}
\hline \multirow{2}{*}{ No } & Name & \multicolumn{3}{|c|}{ Aspect } & The \\
\cline { 3 - 5 } & & Seriousness & Concentration & Cooperation & Score \\
\hline 1. & & & & & \\
\hline 2. & & & & & \\
\hline 3. & & & & & \\
\hline & & & & & \\
\hline
\end{tabular}




\section{Score}

$4=$ always

$3=$ often

$2=$ sometimes

1 = seldom

The highest score $=12$

12
Grade $=\underline{\text { The amount of score }} \times 100$

The highest score

$85-100=\mathrm{A}$

$75-85=\mathrm{B}$

$60-74=\mathrm{C}$

Kalau Anita memperoleh skor 10, maka nilai Anita adalah:

$\underline{10} \times 100=83$. Ini berarti bahwa Anita mendapat nilai B.

12

Berikut ini adalah rubrik penilaian afektif untuk reading yang digunakan oleh guru kelas VIII SMPN B Padang. Aspek yang dinilai adalah self-confident, thinking logically, dan cooperation. Lihatlah tabel 21 berikut ini.

Tabel 21: Rubrik Penilaian Afektif untuk ReadingKelas VIII SMPN B Padang

\begin{tabular}{|l|l|l|l|l|l|}
\hline \multirow{2}{*}{ No } & \multirow{2}{*}{ Name } & \multicolumn{3}{|c|}{ Aspects } & \multirow{2}{*}{$\begin{array}{c}\text { The } \\
\text { Samere }\end{array}$} \\
\cline { 3 - 6 } & $\begin{array}{c}\text { Self- } \\
\text { confident }\end{array}$ & $\begin{array}{c}\text { Thinking } \\
\text { Logically }\end{array}$ & Cooperation & Score \\
\hline 1. & & & & & \\
\hline 3. & & & & & \\
\hline & & & & & \\
\hline
\end{tabular}

\section{Score}

$4=$ always

$3=$ often

2 = sometimes

1 = seldom

The highest score $=12$
Grade $=\underline{\text { The amount of score }} \times 100$

The highest score

$$
\begin{aligned}
& 85-100=A \\
& 75-85=B \\
& 60-74=C
\end{aligned}
$$

Kalau Anitamemperoleh skor 10, maka nilai Anita adalah: $\underline{10} \times 100=83$.Ini berarti bahwa Anita mendapat nilai Baik.

$\frac{10}{12}$

Berikut ini adalah contoh rubrik penilaian afektif untuk writing yang digunakan oleh guru

\begin{tabular}{|c|c|c|c|c|c|}
\hline \multirow[t]{2}{*}{ No } & \multirow[t]{2}{*}{ Name } & \multicolumn{3}{|c|}{ Aspect } & \multirow{2}{*}{$\begin{array}{l}\text { The } \\
\text { Score }\end{array}$} \\
\hline & & $\begin{array}{c}\text { Self- } \\
\text { confident }\end{array}$ & Responsible & $\begin{array}{l}\text { Thinking } \\
\text { critically }\end{array}$ & \\
\hline 1. & & & & & \\
\hline 2. & & & & & \\
\hline$d s t$ & & & & & \\
\hline
\end{tabular}
bahasa Inggris kelas VIII SMPN B Padang.

Tabel 22: Rubrik Penilaian Afektif untuk WritingKelas VIII SMPN B Padang

\section{Score}

$4=$ always

$3=$ often

2 = sometimes

1 = seldom

The highest score $=12$
Grade $=\underline{\text { The amount of score }} \times 100$ The highest score

$85-100=A$

$75-85=B$

$60-74=C$

Kalau Anita memperoleh skor 10, maka nilai Anita adalah:

$\underline{10} \times 100=83$. Ini berarti bahwa Anita mendapat nilai Baik.

12 
Bentuk-bentuk penilaian afektif di atas menunjukkan bahwa guru bahasa Inggris SMPN Kota Padang menggunakan rubrik penilaian yang berbeda dalam melakukan penilaian afektif. Perbedaan itu dapat dilihat dari aspek penilaian dan cara pensekoran.

\section{c. Penilaian Psikomotor}

Penilaian psikomotor berkaitan dengan motorik halus dan kasar yang meliputi: gerakan refleks, gerakan dasar (basic fundamental movements), gerakan persepsi (perceptual abilities), gerakan kemampuan fisik (physical abilities) dan gerakan terampil (skilled movements). Dalam pembelajaran bahasa Inggris, penilaian psikomotor mencakup ekspresi dan gerakan tubuh dalam berbicara. Secara eksplisit belum ada rubrik yang dibuat guru untuk penilaian psikomotorik dalam menilaian keterampilan psikomotor pada pembelajaran bahasa Inggris di SMP Kota Padang.

\section{Pelaksanaan penilaian otentik dalam proses pembelajaran}

Jenis penilaian dalam proses pembelajaran meliputi penilaian kognitif, afektif dan psikomotor. Jawaban guru bahasa Inggris tentang penilaian dalam pembelajaran dapat dikategorikan kepada tiga hal, yaitu penilaian kognitif, afektif, dan psikomotor.

1) Penilaian kognitif

Penilaian kognitif berupa retelling the story, kemampuan menyimak, merangkum, memahami bacaan, dan menulis.

2) Penilaian afektif

Penilaian afektif berupa sikap, tanggungjawab, kerjasama, keaktifan, ketekunan, percaya diri, dan berfikir kritis.

3) Penilaian psikomotor

Penilaian psikomotor berupa interview, performan kelompok atau berpasangan, demonstration, dan bermain peran (role play)

Jawaban pertanyaan kepada siswa yang menyangkut dengan penilaian dalam proses pembelajaran menunjukkan bahwa penilaian kognitif lebih banyak ditemukan dalam keterampilan mendengarkan (listening) dan membaca (reading). Penilaian affektif dapat ditemukan pada keterampilan mendengarkan (listening), membaca (reading) dan menulis (writing). Sedangkan penilaian psikomotor dapat ditemui dalam pebelajaran adalah keterampilan berbicara (speaking) dan menulis (writing). Secara rinci jawaban siswa dapat disampaikan sebagai berikut:

a) Penilaian Kognitif

Penilaian kognitif yang diterima siswa berupa (1) pemahaman terhadap lagu, teks, percakapan, dan berita yang diputar guru, (2) melengkapi teks lagu yang dikosongkan (filling in), (3) menyambung kalimat yang dibicarakan guru, (4) memahami maksud teks tulis, (5) menjawab soal atau membuat kesimpulan berdasarkan cerita yang didengar atau film yang ditonton,

b) Penilaian Afektif

Dalam hal afektif, penilaian yang diterima siswa biasanya berupa keseriusan dan ketelitian dalam mendengarkan dan membaca, kejelasan dalam memberi keterangan, ketelatenan dalam berbicara, cara berbicara yang baik, kerapian dalam menulis,

c) Penilaian psikomotor

Penilaian bahasa Inggris dalam hal psikomotor yang diterima siswa adalah latihan debat, pidato, bermain peran, berdialog, presentasi, main drama, dan menulis puisi dan pengumuman.

Salah satu ciri penilaian otentik adalah penilaian diberikan berkesinambungan selama proses pembelajaran. Indikator yang digunakan untuk menilai implementasi pelaksanaan penilaian otentik dalam proses pembelajaran adalah; (a) aktivitas pembelajaran, (b) tugas-tugas yang diberikan, (c) penilaian dalam pembelajaran, (d) acuan penilaian, dan (e) jenis-jenis penilaian.

\section{a. Aktivitas pembelajaran}

Aktivitas pembelajaran menyangkut dengan kegiatan yang dilakukan guru dan siswa selama proses pembelajaran untuk mencapai tujuan pembelajaran. Disamping menjelaskan materi pelajaran, aktivitas pembelajaran diikuti dengan pemberian tugas dan tes.

Aktivitas pembelajaran yang dinilai dalam proses pembelajaran yang dilakukan oleh guru bahasa Inggris SMPN Kota Padang, adalah sebagai berikut: (1) Menjawab pertanyaan, (2) Group work, (3) Individual work, (4) Dictation, (6) Diskusi kelompok, (7) Latihan, (8) Tugas, (9) Keaktifan 56 
bertanya dan menjawab pertanyaan, (10) Motivasi, (11) Sikap, (12) Disiplin, (13) Kejujuran, (14) Tanggungjawab terhadap tugas yang diberikan, (15) Performance, baik individu maupun kelompok, (16) Project individu, (17) Discussing vocabulary, (18) Listening of the dialogues, expressions, (19) Listen and repeat the correct pronunciation and intonation, (20) Practice the expression, dan (21) Identify the information from the text/recording. Dari aktifitas yang diberikan guru di atas, terlihat bahwa ketiga aspek penilaian, yaitu kognitif, afektif, dan psikomotor mendapat penilaian dalam proses pembelajaran.

Sehubungan dengan aktifitas pembelajaran listening di atas, dari kuesioner yang diberikan kepada siswa didapat informasi tambahan bahwa guru juga memberikan materi-materi yang cukup menarik bagi siswa seperti mendengar lagu, mendengar berita, dan mendengar percakapan. Dari proses pembelajaran listening ini bentuk latihan yang diberikan menurut siswa adalah menjawab pertanyaan setelah diperdengarkan sebuah teks, melengkapi kalimat melalui mendengar lagu, dan mengisi kalimat yang kosong.

Dari beberapa aktifitas pembelajaran listening yang diikuti oleh siswa yang paling mereka senangi adalah mendengar lagu kemudian mengisi liriknya yang kosong, mendengar guru membaca cerita bahasa Inggris, dan mendengar percakapan dalam bahasa Inggris. Ini membuktikan bahwa aktivitas pembelajaran tertentu sangat memotivasi mereka untuk belajar lebih baik.

Pada kegiatan speaking, aktivitas pembelajaran yang dilakukan guru, menurut siswa, antara lain berbicara di depan kelas (short speech), dialog bersama teman, presentasi membuat masakan dan minuman, games, story telling, dan debat. Diantara aktivitas pembelajaran tersebut, yang paling disenangi siswa adalah membuat percakapan (dialog), bercerita, games, presentasi di depan kelas, dan berpidato. Siswa juga menyadari bahwa guru menilai intonasi saat berbicara, cara berbicara, grammar, dan kemampuan berbicara. Hal ini berarti guru telah menyampaikan kepada siswa unsurunsur yang akan dinilai dalam keterampilan berbicara, sehingga siswa dapat mempersiapkan diri dan berusaha untuk tampil maksimal ketika mereka mendapat giliran untuk berbicara.

Pada pembelajaran reading, aktivitas yang dilakukan guru antara lain membaca sebuah teks lalu memberi pertanyaan, melancarkan membaca, membaca buku, membaca dongeng, menyuruh siswa membaca teks di depan kelas. Aktivitas yang paling disenangi siswa antara lain membaca sebuah cerita dan membaca teks yang menarik. Siswa juga mengetahui apa yang akan dinilai dalam membaca seperti pemahaman maksud suatu paragraf, kelancaran membaca, penyampaian kesimpulan, dan kemampuan mengeja.

Aktivitas dalam pembelajaran writing antara lain membuat karangan, membuat pidato, membuat pengumuman, dan menyusun kalimat menjadi paragraf. Aktivitas pembelajaran yang paling disenagi siswa anata lain menulis karangan, menyusun kalimat menjadi satu paragraf, menceritakan suatu tempat dan menulisnya, dan membuat surat. Siswa juga mengetahui apa yang dinilai dalam writing seperti kerapian tulisan, vocabulary, struktur, dan cara penulisan huruf yang benar.

Dari analisa di atas dapat dinyatakan bahwa aktivitas pembelajaran yang dilakukan dapat dipahami oleh siswa sebagai upaya untuk meningkatkan kemampuan berbahasa Inggris siswa. Di samping itu siswa juga mengetahui hal-hal yang akan dinilai dalam masing-masing keterampilan berbahasa yang mereka lakukan.

\section{b. Tugas-tugas yang diberikan guru}

Tugas yang diberikan guru kepada siswa dapat berupa tugas terstruktur dan tugas mandiri. Tugas-tugas yang diberikan untuk dinilai dalam proses pembelajaran dapat dikelompokkan atas dua jenis, yaitu tugas lisan dan tugas tertulis.

a. Tugas Lisan

Tugas Lisan mencakup (1) menjawab pertanyaan, (2) membaca teks, (3) bermain peran, (4) presentasi, (5) diskusi dengan teman sebangku, dan (6) asking and giving information

b. Tugas Tertulis

Tugas tertulis berupa (1) menjawab pertanyaan, (2) fill in, (3) complete the paragraph (4) melengkapi teks (completion), (5) matching, (6) menyusun kata menjadi kalimat, (7) menulis kalimat, (8) question and answer, (9) menyusun kalimat acak, dan (10) essay

Tugas yang diberikan guru cukup bervariasi, sehingga siswa dapat mempraktekkan bahasanya dengan berbagai bentuk tugas yang diberikan, baik secara tertulis maupun lisan. 
Jawaban siswa tentang tugas yang diberikan guru sejalan dengan apa yang telah dikemukakan oleh guru di atas. Tugas lisan mencakup menjawab pertanyaan, melengkapi dialog (fill in), berbicara di depan kelas, mempresentasikan tugas, membaca percakapan, diskusi, membuat dialog berkelompok, dan membaca teks. Tugas tulisan mencakup menjawab pertanyaan, membuat paragraf, membuat kalimat, menulis cerita, dan menyusun kalimat menjadi paragraf.

\section{c. Acuan penilaian}

Acuan penilaian adalah hal-hal yang harus dipertimbangkan guru dalam menilai keterampilan berbahasa Inggris siswa. Penilaian yang diberikan guru dapat mengacu kepada tiga aspek penilaian yaitu kognitif, afektif dan psikomotor. Masing-masing aspek penilaian tersebut mempunyai acuan penilaian.

a. Kognitif; mencakup taxonomy Bloom, rubrik penilaian, dan ketepatan jawaban

b. Afektif; mencakup keaktifan siswa, motivasi, dan sikap

c. Psikomotor; mencakup unjuk kerja dan intonasi

Acuan penilaian dilihat dari sisi komponen empat keterampilan berbahasa yang dinilai dapat dinyatakan sebagai berikut.

a. Listening comprehension; spelling, guessing the meaning, dan answering the questions,

b. Speaking; pronunciation, spelling, grammar, content, accuracy, fluency, performance, clarity, dan volume

c. Reading; understanding the instruction, doing the action

d. Writing; content, grammar, spelling, vocabulary, coherency (hubungan antar gagasan), accuracy, kejelasan makna, manajemen wacana, dan leksikogramatika

Acuan penilaian di atas digunakan guru bahasa Inggris untuk menyusun rubrik penilaian keempat keterampilan berbahasa. Masing-masing keterampilan berbahasa menggunakan acuan yang berbeda.

\section{d. Jenis-jenis penilaian}

Jenis-jenis penilaian yang diberikan dalam proses pembelajaran

a. Written test; pilihan ganda, melengkapi, menyusun, benar-salah, choose the best answer, write the instruction

b. Oral test; tanya jawab, presentasi, percakapan (dialogue), respond, dictation

c. Performance test; portofolio, kinerja, role play, monologue, recount, exposition

d. Project; essay writing/compositio, presentation

\section{Pelaksanaan penilaian otentik dalam menilai hasil belajar siswa}

Nilai akhir merupakan akumulasi dari beberapa nilai yang diberikan selama proses pembelajaran. Menurut guru bahasa Inggris SMPN Kota Padang pertimbangan yang dilakukan dalam menentukan nilai akhir adalah.

a. Nilai Ujian Harian (UH)

b. Nilai Proses (tugas-tugas dan kehadiran)

c. Nilai Tengah Semester

d. Nilai Akhir Semester

e. Nilai harian, nilai tengah semester, nilai akhir semester $(70 \%+10 \%+20 \%)$

Dari uraian keenam komponen di atas dapat dilihat bahwa penilaian yang dilakukan guru bahasa Inggris SMPN Kota Padang sangat bervariasi dan berfokus pada unjuk kerja.

Pelaksanaan penilaian otentik dalam menilai hasil belajar siswa dapat dilihat dalam tujuh indikator, yaitu: (1) pertimbangan nilai harian dalam menentukan nilai akhir, (2) penggunaan penilaian otentik untuk ujian tengah semester, (3) penggunaan penilaian otentik untuk ujian akhir semester, (4) pertimbangan nilai keterampilan, (5) pertimbangan nilai pengetahuan, (6) pertimbangan nilai sikap/afektif, dan (7) pertimbangan nilai kerajinan

\section{a. Pertimbangan nilai harian dalam menentukan nilai akhir}

Nilai harian merupakan komponen yang sangat berpengaruh dalam menentukan nilai akhir siswa. Di dua sekolah SMPN Kota Padang ini, persentase nilai harian dalam menentukan nilai akhir berbeda. Di SMP A Padang, nilai harian diberi bobot 30\%, sementara di SMPN 8 Padang, nilai harian diberi bobot sangat tinggi, yatu $70 \%$, nilai ujian tengah semester $10 \%$ dan nilai ujian akhir semester 20\%. Oleh karena itu, di SMPN B Padang nilai harian sangat menentukan nilai akhir. Di SMPN A Padang, nilai tengah semester diberi bobot $20 \%$ dan nilai semester diberi bobot $10 \%$. Secara keseluruhan di kedua sekolah ini, nilai harian mendapat bobot terbesar dibandingkan nilai ujian tenga semster dan akhir semester.

58 


\section{b. Penggunaan Penilaian Otentik untuk Ujian Tengah Semester}

Untuk mengetahui apakah ujian tengah semester menggunakan penilaian otentik, mari kita lihat jenis soal yang disusun oleh guru. Materi ujian tengah semester hanya mengacu pada keterampilan membaca dan keterampilan menulis. Jenis soal yang diberikan adalah multiple choice dan melengkapi kalimat rumpang. Dilihat dari jenis soalnya, kelihatannya guru tidak menggunakan penilaian otentik.

Dilihat dari materi yang diuji, bahan-bahan yang digunakan adalah materi yang otentik berupa brosur, pengumuman, undangan, dsb. Dilihat dari komponen penilaian otentik, soal ini hanya menguji kemampuan kognitif saja, tidak sampai pada psikomotor dan afektif.

\section{c. Penggunaan Penilaian Otentik untuk Ujian Akhir Semester}

Sama dengan ujian tengah semester, ujian akhir semester juga hanya mengacu kepada keterampilan membaca dan keterampilan menulis. Jenis soal yang diberikan juga berupa multiple choice, dengan tingkat pertanyaan pemahaman, pengetahuan dan analisis (tingkatan 1, 2, 3 dalam Taxonomi Bloom).

Dilihat dari materi yang diujikan, materi soal yang diberikan berbentuk materi otentik seperti brosur, pengumuman, undangan, caution, greeting card, advertisement, label, letter, dsb. Materi uji ini diberikan menyerupai bentuk aslinya. Oleh karena itu dari sisi materi teks yang diuji sudah mendekati otentik.

Dilihat dari komponen penilaian otentik, penilaian yang diberikan baru berupa penilaian pengetahuan, belum mencakup penilaian psikomotor dan afektif. Hal ini disebabkan karena ujian tengah semester dan ujian akhir semester dibuat dalam pola tes standar (standardized test). Oleh karena itu, bentuk soal yang muncul sesuai dengan kriteria tes-tes standar.

\section{d. Pertimbangan nilai pengetahuan}

Pertimbangan nilai pengetahuan untuk reading misalnya menanyakan informasi tentang main idea of the text, explicit information of the text, implicit information of the text, synonym of the word, antonym of the word, dan reference. Siswa harus menggunakan pengetahuan vocabulary dan grammar untuk bisa memahami teks secara keseluruhan. Disamping itu, siswa juga harus mempunyai latar belakang ilmu tentang dunia yang berhubungan dengan isi teks reading.

Untuk writing, pertimbangan nilai pengetahuan dapat dilihat pada kemampuan siswa menyusun kalimat, memilih kosa kata yang tepat, dan bagaimana menyampaikan pesan berdasarkan pengetahuan mereka tentang jenis-jenis teks. Siswa harus mengetahui perbedaan antara teks descriptive, narrative, exposition, recount, procedure, dan jenis-jenis teks fungsional untuk bisa menulis dengan baik dan benar. Masing-masing teks mempunyai ciri-ciri yang berbeda yang disebut juga dengan istilah generic structure.

\section{e. Pertimbangan nilai keterampilan}

Pertimbangan nilai keterampilan adalah unjuk kerja siswa dalam menggunakan bahasa, baik lisan maupuan tulisan. Keterampilan berbahasa lisan yang memerlukan pertimbangan nilai keterampilan misalnya pada aktivitas bermain peran (role play), bercakap-cakap, dan mendemonstrasikan suatu aktivitas tertentu. Keterampilan berbahasa tulis yang memerlukan nilai keterampilan misalnya menulis essay, narasi, dan teks prosedur.

\section{f. Pertimbangan nilai sikap/afektif}

Pertimbangan nilai sikap/afektif adalah kemauan untuk belajar, keaktifan, ketekunan, perhatian, konsentrasi, kerjasama, disiplin, kerajinan, kesopanan, keberanian, ketelitian, tingkah laku, sikap dalam belajar (kepada guru dan kepada teman), dan tanggung jawab dalam melakukan tugas. Nilai afektif ini bisa diobservasi selama proses pembelajaran. Pada setiap keterampilan berbahasa unsur afektif yang dinilai juga berbeda.

\section{g. Pertimbangan Nilai Kerajinan}

Pertimbangan nilai kerajinan yang dimaksud terdiri dari kehadiran setiap pertemuan dalam kelas, keaktifan selama proses pembelajaran, serta frekuensi penyerahan tugas yang diberikan.

\section{Permasalahan dalam Penialain Otentik}

Berikut ini akan diungkapkan beberapa permasalahan yang dihadapi guru dalam mengimplementasikan asesmen otentik. 


\section{a. Kebutuhan pelatihan}

Ketika ditanya "apakah bapak/ibu memahami bagaimana membuat penilaian otentik", hanya $20 \%$ menjawab ya, $20 \%$ sedikit, dan $60 \%$ belum dan tidak memahami bagaimana membuat penilaian otentik. Ini membuktikan bahwa, penilaian otentik yang dilakukan oleh guru baru sebatas administrasi dalam RPP, tetapi belum terlihat aplikasinya di lapangan.

Oleh karena itu, ketika ditanya "Apakah masih butuh pelatihan?", semua guru menjawab "sangat membutuhkan". Mereka menyadari bahwa untuk bisa membuat penilaian otentik, guru harus mengetahui detail keterampilan yang harus dinilai dan bagaimana cara menilainya.

\section{b. Kecukupan panduan}

Ketika ditanya, "Apakah ada panduan yang dipedomani untuk membuat penilaian otentik", hanya $40 \%$ guru yang menjawab mempunyai panduan, sementara $60 \%$ guru lagi menyatakan belum mempunyai panduan. Hal ini membuktikan bahwa panduan pembuatan penilaian otentik belum tersosialisasi kepada semua guru bahasa Inggris, termasuk guru bahasa Inggris SMPN Kota Padang.

Kepada guru yang telah mempunyai panduan, ketika ditanya lebih lanjut "Apakah panduan penilaian yang ada memadai untuk membuat penilaian otentik?", semuanya menjawab "belum memadai". Oleh karena itu diperlukan upaya agar guru bahasa Inggris SMPN Kota Padang betulbetul memahami penilaian otentik dan mengimplementasikan penilai tersebut dalam proses pembelajaran bahasa Inggris di sekolah masing-masing.

\section{SIMPULAN DAN SARAN}

\section{Simpulan}

Penelitian ini menginvestigasi implementasi penilaian otentik dalam pembelajaran bahasa Inggris SMPN Kota Padang. Berdasarkan temuan penelitian seperti dijelaskan di atas, dapat diambil beberapa simpulan sebagai berikut.

1) Kemampuan guru bahasa Inggris Kota Padang dalam menyusun perangkat penilaian otentik cukup memadai. Dari analisis dokumen Rencana Pelaksanaan Pembelajaran yang dibuat oleh guru SMPN Kota Padang, kelihatan bahwa guru sudah mampu menyusun perangkat penilaian otentik, terutama untuk menilai keterampilan speaking dan writing. Namun demikian, ada beberapa rubrik penilaian otentik yang tidak sesuai dengan keterampilan berbahasa yang dinilai. Kemudian, melihat begitu beragamnya jenis teks yang harus dinilai, dibutuhkan beberapa jenis rubrik penilaian sesuai dengan jenis teks yang ada, oleh karena itupengetahuan guru untuk menyusun perangkat penilaian otentik ini masih perlu ditingkatkan.

2) Pelaksanaan penilaian otentik dalam proses pembelajaran belum secara utuh dilaksanakan dalam menilai keterampilan berbahasa. Meskipun guru sudah memiliki rubrik penilaian yang rinci pada masing-masing keterampilan berbahasa (listening, speaking, reading, dan writing), namun pada sebagian besar aktivitas pembelajaran, penilaian masih bersifat global, belum menggunakan rubrik secara taat azas seperti yang telah dinyatakan pada Rencana Pelaksanaan Pembelajaran yang dibuat guru.

3) Penilaian otentik dalam menilai proses pembelajaran sudah dilakukan, akan tetapi belum untuk ujian tengah semester dan akhir semester. Meskipun demikian, materi ujian sudah menggunakan materi pembelajaran otentik. Hal ini dapat dilihat dari jenis teks yang digunakan sebagai bahan ujian tengah semester dan akhir semester.

4) Permasalahan yang masih dihadapi guru adalah belum adanya pedoman untuk melaksanakan penilaian otentik. Oleh karena itu guru sangat membutuhkan pelatihan agar dapat melaksanakan penilaian otentik yang sebenarnya.

\section{Saran} berikut.

Berdasarkan kesimpulan penelitian di atas maka peneliti mengajukan beberapa saran sebagai

1. Guru Bahasa Inggris SMPN Kota Padang masih membutuhkan pelatihan membuat perangkat penilaian otentik dalam menilai empat keterampilan berbahasa (listening, speaking, reading, dan writing) 
2. Perlu disusun panduan penyusunan penilaian otentik yang aplikatif sebagai pedoman bagi guru bahasa Inggris dalam melakukan penilaian otentik, baik di SMPN A dan B maupun SMP/MTs lainnya.

3. Melihat begitu beragamnya rubrik penilaian untuk masing-masing keterampilan berbahasa, perlu dikembangkan model penilaian otentik yang sesuai dengan keterampilan berbahasa pada masing-masing tingkatan sekolah, khususnya tingkat SMP/MTs.

\section{REFERENSI}

Badan Standar Nasional Pendidikan (BSNP).2006. Standar Isi untuk Satuan Pendidikan Dasar dan Menengah. Jakarta: Badan Standar Nasional Pendidikan

Brown, H, Douglas and Priyanvada Abeywickrama. 2010. Language Assessment Principles and Classroom Practices (Second Edition). New York: Pearson Education, Inc

Burns, Robert B. 1995. Introduction to Research Metods. Melbourne: Longman Australia Pty. Ltd.

Depdiknas. 2001. Panduan Pelaksanaan Terbatas Kurikulum Berbasis Kompetensi. Jakarta: Pusat Kurikulum.

Depdiknas. 2002. Kurikulum Berbasis Kompetensi: Penilaian Berbasis Kelas. Jakarta: Pusat Kurikulum.

Depdiknas. 2003. Pedoman Umum Pengembangan Penilaian. Jakarta: Depdiknas.

Depdiknas. 2004. Pengembangan Silabus. Jakarta: Depdiknas.

Depdiknas. 2006. Rancangan Penilaian Hasil Belajar. Jakarta: Depdiknas

Djiwandono, M.S. 1996. Tes Bahasa dalam Pengajaran.Bandung: Penerbit ITB.

Gay, L.R. 1992. Educational Research: Competencies for Analysis and Aplication (Fourth Edition). New York: Maxwell Macmillan International

Haryono, Agung. 2009. "Authentic Assessment dan Pembelajaran Inovatif dalam Pengembangan Kemampuan Siswa“, JPE.Volume 2, Nomor 1, 2009 (1-12).

Imran, Syaiful. 2012. Authentic Assessment. http://ipankreview.wordpress.com/, diunduh 22 Maret 2012.

Moon T.R. et. al. 2005. "Development of Authentic Assessments for the Middle School Classroom", The Journal of Secondary Gifted Education. Vol XVI No.2/3 Winter/Spring.

Mulyasa. 2002. Kurikulum Berbasis Kompetensi; Konsep, Karakteristik, dan Implementasi. Bandung: Remaja Rosda Karya

Nasar. 2006. Merancang Pembelajaran Aktif dan Kontekstual Berdasarkan "SISKO” 2006. Jakarta: PT Gramedia Widiasarana Indonesia.

O’Malley, J. Michael dan Lorraine Valdez Pierce 1996.Authentic Assessment for English Language Learners: Practical Approaches for Teachers. New York: Addison-Wesley Publishing Company

Taufina. 2009. "Authentic Assessment dalam Pembelajaran Bahasa Indonesia di Kelas Rendah SD”. PEDAGOGI: Jurnal Ilmiah Ilmu Pendidikan. Volume IX No.1 April 2009 (113-120)

Taylor, Ronald, L. 1998. Assessment of Exceptional and Psychological Procedures.Florida: Atlantic University 